\title{
Determinants of private school participation: all about the money?*
}

\author{
Jake Anders $^{1}$, Francis Green ${ }^{2}$, Morag Henderson ${ }^{3}$ and Golo Henseke ${ }^{2}$ \\ ${ }^{1}$ Centre for Education Policy \& Equalising Opportunities, UCL Institute of Education \\ ${ }^{2}$ LLAKES Centre for Research on Learning and Life Chances, UCL Institute of Education \\ ${ }^{3}$ Centre for Longitudinal Studies, UCL Institute of Education
}

\begin{abstract}
For those who grew up in Britain in the latter half of the 20th century, there is known to be a strong association between social class or family income and attending a private school. However, increasing private school fees and promotion of school choice in the state sector have potential implications for the predictors of participation in private schooling in the 21st century. In this paper, through analysis of rich, longitudinal data from a recent, representative birth cohort study, we provide new evidence on this issue. Given the high and rising fees required to send a child to private school, one might think that the decision is entirely connected with financial resources. However, while these remain an important factor, we argue that other determinants are also important. In particular, we highlight the importance of parental values and geographical proximity to high-quality state school alternatives: a one standard deviation increase in levels of parental traditional values is associated with 2.5 percentage point higher probability of their child attending a private school, while each minute of additional travel time to the nearest state school judged 'Outstanding' by England's schools inspectorate is associated with a 0.2 percentage point higher probability of attending a private school. We also examine the characteristics of those who ' $m i x$ and match' state and private schooling, noting their similarity to private school attendees in terms of their values but lower levels of financial resources.
\end{abstract}

Keywords: Private education, Independent schools, Geographical proximity, Family income.

Acknowledgements: We are grateful to UKRI Economic and Social Research Council for supporting this research under its Secondary Data Analysis Initiative (ES/R003335/1). Thanks to Gabriela Melis for advice on the construction and interpretation of the values measures. Thank you also to David Church at the UCL Centre for Longitudinal Studies for constructing the travel time measures. Thanks to UK Data Service Secure Lab team for their assistance with data access.

\section{Introduction}

For those who grew up in Britain in the latter half of the 20th century, there is known to be a strong association between social class or family income and attending a private school (e.g. Dearden et al., 2011; Blow et al., 2011). Although those attending private schools make up a small proportion of those attending English schools (around 9\% attend one at some point during their educational careers according to Green et al., 2018), it is important to understand the factors that predict who do so. Unlike

\footnotetext{
* Contact details: Jake Anders (jake@jakeanders.uk), Centre for Education Policy \& Equalising Opportunities, UCL Institute of Education, 20 Bedford Way, LONDON WC1H 0AL
} 
in a number of other countries, private school attendance in Britain is associated with significant advantages in terms of educational attainment (Dearden et al., 2002; Sullivan and Heath, 2003; Parsons et al., 2017) and labour market advantages (Green et al., 2012; Sullivan et al., 2014; Green et al., 2017; Macmillan et al., 2015; Crawford et al., 2016; Belfield et al., 2018) later in life.

Increasing school fees in the private sector (Green et al., 2018) and promotion of school choice in the state sector (Burgess et al., 2019) potentially have important implications for the characteristics of those who participate in private schooling. Given the high and rising fees required to send a child to private school, one might think that the reasons for this decision are entirely connected with family financial resources. However, while this is doubtless an important factor, in this paper we argue that there are a number of other important factors that enter into the decision-making process. Indeed, previous work has highlighted that even among families with high levels of income it is far from the case that all children actually attend a private school (Green et al., 2018): what explains this significant variation in behaviours among parents who are unlikely to be constrained by finance? Previous evidence exploring motivations of those who choose private schooling leads us to hypothesise a potential role of parental values (e.g. Ball, 1997) and of the geographical availability of state-funded schools that parents may see as 'substitutes' for private schools (e.g. Blundell et al., 2010).

Through analysis of a rich, longitudinal dataset from a recent, representative birth cohort study, including geographical data on pupil's proximity to private schools and highly-regarded state-funded alternatives, we provide new evidence on the determinants of private schooling in the 21 st century, including some of the first evidence on the importance of permanent, rather than contemporary, family income in predicting private school attendance. We also examine for the first time the characteristics of those who 'mix and match' (Noakes, 2015) state and private provision at the primary and secondary phases, compared to those whose children remain in one sector throughout.

We begin by describing the institutional context of private schooling in Britain in Section 2 and report on previous literature exploring determinants of demand for private education and the research hypotheses these motivate in Section 3. Next, in Section 4, we introduce our data set. Following this, we set out our methods, including descriptive statistics and regression modelling, in Section 5 and report the results of these in Section 6. Finally, in Section 7 we discuss our findings and conclude.

\section{Institutional context}

Private schools in Britain are sometimes referred to as 'independent schools' or, especially when referring to the most prestigious secondary schools, 'public schools'. Under $10 \%$ of schools in Britain are private with the rest being 'state' schools funded by the government (either directly or indirectly). With the cessation of the Assisted Places Scheme that ran from 1981 till 1997 (Whitty et al., 1998), Britain's private schools receive almost no direct public subsidies: their funding derives almost exclusively from fees, donations and business activities. While they are managed and governed autonomously, three-quarters are registered charities bringing an obligation to provide 'public benefit' (Wilde et al., 2016) in return for a degree of public subsidy through tax relief.

British private schools are generally considered elite institutions, reflecting both the social composition of their intake and their resources (Maxwell and Aggleton, 2015; Reeves et al., 2017). Perpupil resources are approximately three times the average per-pupil funding provided to state-funded schools (Green and Kynaston, 2019). These differences are much larger than those seen between the state and private education sectors in most other developed countries. As such, British private schools can provide smaller class sizes and offer a broader education including a wider range of extra-curricular activities with facilities that are typically generous and well-equipped. All of these advantages may be important reasons for parents to send their children to these schools.

While only about $5 \%$ of secondary-level state-funded schools are permitted to select students on academic merit (termed 'grammar schools'), private schools are free to choose among any students who apply. Approximately half are selective according to children's academic or sporting prowess. They are not required to follow the government's National Curriculum, although most enter their pupils for the same national exams that state secondary school pupils take, since these are the best recognised qualifications for entry to university and other post-secondary education. Since the start of the 1980s, the management of private schools has been modernised and the resources at their disposal have been transformed. 
In the British education system, school choices are generally made at two key ages within the span of compulsory schooling. These are at approximately age 5 (primary school) and age 11 (secondary school), although private primary ('preparatory') schools sometimes run from age 7 to 13 , before a transition to private secondary ('senior') school. Our private school attendance measures (discussed further below) are based on reports at age 7 and 10 for primary and age 14 for secondary; thus, we should avoid mis-measurement due to variation in the transition from primary to secondary.

According to the Independent Schools Council $(2018$, p.3), around 13\% of pupils attending British private schools are 'boarding' pupils, while this is very rare within the state sector. The availability of boarding at a school is likely to reduce the importance of distance to that school for whether it is a viable option in terms of attendance. However, this is mitigated to some degree by the increased fees associated with boarding, with the average annual boarding fee being $£ 33,684$, compared to an average annual day fee (across schools with and without boarding provision) of $£ 14,562$ (Independent Schools Council, 2018, p.18).

Despite a dramatically changing context, including significant changes in education policy around school choice in the state sector (Gorard, 1999; Ball et al., 1997) and dramatic increases in fees (Green et al., 2017), since the 1980s the average participation rate in private education has remained stable at around 7 per cent of all school pupils (Department for Education, 2018). However, this is no guarantee that the characteristics of those choosing to send their children to private schools have remained the same.

\section{Previous evidence and research hypotheses}

This study is not the first to explore the determinants of private schooling quantitatively (Henseke et al., nd), although there is perhaps surprisingly little evidence in an English context. Our research hypotheses are shaped by findings of earlier studies and, as such, in reviewing these findings, we outline the hypotheses that emerge from them for this study.

In this paper we do not just consider whether individuals ever attend private school, but also explore the factors associated with choosing to 'mix and match' (Noakes, 2015) state and private schooling. This provides additional opportunities to understand the interplay of the hypothesised predictors of private schooling from above. For example, is there evidence that families who 'mix and match' share motivations - for example driven by their values or the (un)availability of what they see as high-quality state schooling - with those who choose private schooling, while being different in other respects?

Hypothesis 1. The financial resources and parental values of families who 'mix and match' state and private schooling during their educational careers differ from those who attend private schools consistently throughout their education career.

While financial factors seem likely to be highly important as determinants of private schooling, there are good reasons to suspect that they are not the only important factor. Our own previous work finds that even among the top $1 \%$ of the income distribution only about $50 \%$ of parents send their children to private schools (Green et al., 2018). This suggests that, while having sufficient financial resources might be a necessary condition, it is not a sufficient condition. Furthermore, our proposition that other non-financial factors must play a role chimes with the findings of Ball (1997) that for some "private schooling is a possible but unacceptable choice" (Ball, 1997, p.16), noting the seeming importance of personal values, which are not necessarily well-captured by a measure of their socioeconomic status. Such attitudes have been noted across at least three decades (Fox, 1985; West et al., 1998; Foskett and Hemsley-Brown, 2003). However, we are not aware of previous work that has attempted to model the interplay of such values-led motivation with the financial factors that we have highlighted above.

Hypothesis 2. Parental values explain variation in private school attendance over and above that explained by family income, particularly among families with high levels of income.

An under-explored factor is the geographical availability of substitutes in the shape of state schools that provide some of the characteristics sought by parents who would otherwise purchase private schooling. Evidence focussed purely on state schools have demonstrated the value that parents place on getting their child into a good school through the effect of the presence of a good school on house prices 
(Machin, 2011; Gibbons et al., 2013). Other work has unpacked characteristics of state schools that appear to be particularly valued including academic performance, distance from home and socioeconomic composition (Allen and Burgess, 2013; Burgess et al., 2014, 2019). Blundell et al. (2010) more directly link state school characteristics to private education, finding that higher quality state-school alternatives in a local area is associated with reduced demand for private education. However, this analysis was not based on family data, meaning that the interplay between these factors and other family-level determinants could not be explored. This is a limitation we are able to overcome in our analysis.

Hypothesis 3. Shorter travel times to independent schools are positively associated with demand for private schooling, over and above the relationship between family background and private school attendance.

Hypothesis 4. Shorter travel times to 'well-regarded' state schools are negatively associated with demand for private schooling, over and above the relationship between family background and private school attendance.

Although our primary focus in this paper is on factors beyond finance, it is obviously important to understand the importance of family income so that we can accurately capture this in our modelling; as such, we still contribute to improving understanding of the role of family income in predicting private school attendance. In this respect, much of the existing quantitative evidence on predictors of private schooling comes from a group of inter-related studies by Dearden et al. (2011), Blundell et al. (2010) and Blow et al. (2011). Dearden et al. (2011) use data from the British Household Panel Study (BHPS) to model participation in English private schools, particularly drawing comparisons with determinants in Australia. They find that higher family incomes, having a self-employed parent, having a universityeducated parent, having fewer siblings, and whether one's parents went to a private school are all important and separable predictors of private school participation. Blow et al. (2011), also note the importance of family income, while highlighting that higher levels of inequality in a region is associated with higher demand for private schooling.

However, an important limitation of previous studies of private school attendance is that they use only contemporary income reports, while the literature on the importance of income for educational investments more generally concludes that permanent income is more important than contemporary income for educational investments (Blau, 1999; Chevalier et al., 2013; Carneiro and Ginja, 2016). We argue that this is particularly likely to be the case for long-term investments, such as private school, where it is generally seen as disruptive to a child's education and well-being to move them between schools other than at specific points in time (e.g. the transition between primary and secondary schooling at age 11).

Hypothesis 5. Permanent family income is more important than contemporary family income in predicting private school attendance.

Previous work has not always accounted for the likely non-linearity in the relationship between income and private school attendance highlighted by (Henseke et al., nd), given that below a certain point additional contemporary income is unlikely to materially increase a family's ability to afford private school fees. While we are unable to replicate the same approach to defining this affordability discontinuity as Henseke et al. (nd) in the dataset we use in this paper, we approximate this using a fixed point on the income distribution (the 10th percentile) based on Henseke et al.'s findings and a non-parametric examination of the relationship between income and private school attendance in our dataset.

Hypothesis 6. Additional family income is a stronger predictor of private school attendance among families with already relatively high levels of income.

In addition to our research hypotheses based on prior evidence, we also set out an exploratory hypothesis, in which we explore the extent to which having an older sibling who attends a private school acts as a revealed preference indicator for private schooling within the family, over and above the role of the characteristics already discussed (i.e. family income, distance to private school, and family values) which would imply that this picks up on otherwise unobservable within-family propensity to choose a private school. This will also allow us to explore how this way of capturing family propensity 
to privately educate attenuates the role of the other observable family-level factors in predicting private school attendance for the younger sibling.

Hypothesis 7. Older sibling attendance at a private school explains younger sibling attendance at a private school conditional on our other measurable family characteristics; conditioning on this predictor will attenuate the role of family values in predicting whether an individual attends a private school.

\section{Data}

To conduct our analysis, we use the Millennium Cohort Study (MCS), restricting our attention to the English sample because of differences in the education market between the constituent countries of the UK. The MCS follows a cohort born in 2000/1, including interviews with, and assessment of, the children themselves, their parents, other family members, and their teachers. We use data from sweeps at ages $1,7,10$, and 14 . Our sample is also restricted to those for whom we can identify private school attendance at either age 7 or 10 and at age 14, and those for whom we have income measurements from at least waves 2 and 4 (ages 3 and 10). Item non-response on all variables included in modelling (other than private school attendance and family income) is handled using a mean imputation strategy; use of multiple imputation makes no difference to our substantive findings (Little and Rubin, 1989). The longitudinal dataset includes a rich set of data on family circumstances, parental values, cognitive attainment (including data linked in from the National Pupil Database), geographical identifiers (used along with external data on location of private and well-regarded state-funded schools to construct travel times; further information below) and educational career.

Importantly for this work, the MCS includes questions on whether the cohort member is attending a school at which fees must be paid (which we take as our definition of a private school) based on questions covering both primary (pre-11) and lower secondary (post-11) phases of schooling.

'Permanent' equivalised family income, based on averaging parental income measures available across all six waves of MCS data available up to age 14, is used as a more long-term indicator of financial resources than income measured at any particular time point (Blau, 1999; Chevalier et al., 2013; Carneiro and Ginja, 2016). We explore the importance of these long-term, rather than short-term financial resources by also including contemporary measures of income in some of the modelling later in the paper. However, as noted in the introduction, we also hypothesise that there are other influences at play. To explore the importance of one of these, we construct measures based on parents' responses to thirteen statements about their values put to them while their child was an infant (Wave 1), including propositions such as 'Couples who have children should not separate' and 'It is alright for people to have children without being married'. Parents are asked how much they agree with these statements and these responses are used in an exploratory factor analysis from which we ultimately choose to extract three measures of latent factors, as follows. Full details of this approach are reported in the Values Measures methodological supplement.

To model the importance of distance to different kinds of school, we take advantage of the fact that the MCS includes information on the individuals' home addresses. We cannot access these directly (for statistical disclosure control reasons). We therefore commissioned newly constructed data on the travel time from these addresses to the nearest private school (separately for boys and girls, given the prevalence of single-sex private school), to the nearest state school judged 'Outstanding' by Ofsted (England's schools inspectorate), and to the nearest grammar school (Church, 2018). We acknowledge a number of potential limitations in constructing this measure. First, we appreciate that school quality is a contested concept and, in particular, that schools judged 'Outstanding' by Ofsted are not necessarily those best placed to produce the most 'well-rounded' individuals at the end of their time in the school, for example. However, we posit that parents are likely to choose schools in the basis of these kind of metrics (Allen and Burgess, 2013). It seems likely that motivations for this choice might include some of the same desire to choose their offspring's peers (Burgess et al., 2014) that is often posited as a driver of demand for schooling. Second it is of course the case that parents (or those planning to become parents) may base their choice of where to live at least partly on their preferences for schooling (Machin, 2011). As such, distance to certain kinds of school may be affected by these preferences, rather than vice versa. To attempt to investigate this possibility, we examined change in travel time to independent 
school and to well-regarded state schools among those who moved between their child being 7 and their child being 10 (i.e. in the run up to decisions regarding secondary school). We were surprised to find that the average travel time to the nearest 'Outstanding' state school increased slightly between the two sweeps among those who moved (compared to essentially no change among those who did not). Of course, this does not mean that there is no issue of endogeneity in our analysis, but it may cause less bias than might be expected.

\section{Methods}

\subsection{Descriptive analysis}

Our initial analysis sets out the prevalence of private schooling within our analysis both at primary and secondary phases of education and considers how these intersect. This is carried through a cross tabulation of binary private school attendance variables during primary school and during secondary school. This provides information on the rates of attendance at each phase, allows us to see rates of transition between the sectors between phases, and identifies the groups of attendance patterns for the next stage of analysis i.e. private/private, private/state, state/private and state/state. The private/state and state/private groups are merged into a 'combined' group as Hypothesis 1 concerns this group as a whole.

Having identified these three groups, we report mean values of key characteristics about each group (State, Combination, and Private) and the sample as a whole, also providing the standard deviation of the full sample to contextualise the differences between the groups. These descriptive statistics are calculated taking into account the appropriate sampling and non-response weights provided in the dataset. Finally, unweighted counts of the number of individuals in each group are provided. In particular, comparing the characteristics of the Combination and Private groups will provide evidence on to confirm or reject Hypothesis 1.

\subsection{Regression modelling}

Our empirical strategy is based on a simple human capital model in which parents are concerned about their children's future life chances (Becker and Tomes, 1986; Acemoglu and Pischke, 2001) and hence make decisions over school choice (specifically, here, whether or not to send their child to a private school) based on an assessment of costs and future benefits. Parents' assessments of costs and benefits, which are not limited to the financial, will vary depending on factors including personal values and attitudes (for example shaping what future outcomes they desire for their child) and their location (for example relative to private and state school alternatives).

We use probit regression modelling to estimate a binary choice model of participation in private schooling at either primary or secondary phases i.e. ever attending private school. The outcome measure is formally defined as an indicator variable which takes a value of 1 if private school is reported at 7 , 10 or 14, and takes a value of 0 otherwise. Models of this outcome are shown beginning with $E$ in the outcome tables to distinguish them from the alternative outcome measures (discussed below).

The regression models take the form:

$$
\begin{aligned}
y_{i} \quad & \alpha \\
& +\beta_{1} \text { Perm. Income (lower) } / \text { week }_{\mathrm{i}}+\beta_{2} \text { Perm. Income (upper) } / \text { week }_{\mathrm{i}} \\
& +\gamma \mathbf{X}_{\mathbf{i}}+\varepsilon_{i}
\end{aligned}
$$

where $\alpha$ is a constant term, Perm. Income is a measure of 'permanent income' averaged across income measures at all available sweeps modelled as a piecewise linear function with a single kink to allow a differential relationship below and within the top $10 \%$ of the income distribution (as discussed above), 
$\mathbf{X}_{\mathbf{i}}$ is a vector of control variables varying by model and discussed below, and $\varepsilon_{i}$ is an error term. The substantive interpretation of our results does not change if we instead use logistic regression.

The baseline model (M0) also includes the following covariates: housing tenure, Government Office Region, and gender. These covariates aim to control for, among other issues, regional differences in the availability of private schooling and potential differences in demand associated with variable levels of inequality within a region (Blundell et al., 2010). The results from this model allow us to explore the importance of income (both permanent and contemporary, as discussed above) in predicting private school participation after taking account of a proxy for wealth (home ownership) and other structural characteristics that may separately influence demand for private schooling. We also carried out modelling including a measure of pupil prior academic attainment at age 5 (Bracken School Readiness score), however, we came to the view this should not be included in order to estimate the full effect of our variables of interest. In any event, inclusion of this covariate makes little difference to other conditional associations in the model.

Our first model (M1) adds our measures of parental values. This model allows us to test Hypothesis 2 that family income and parental values both separately influence demand for private schools. We build on this in the second model (M2) by allowing the relationship between parental values and demand for private schooling to vary across the income distribution by including interactions between the values variables and being in the top $10 \%$ of the income distribution (in line with the piecewise linear function for income discussed above).

Our next set of models explore Hypotheses 3 and 4 regarding the importance of distance to private schools and to highly regarded state school substitutes in determining demand for private schooling. To capture the former, all three include travel time to the nearest private school (derived separately for boys and girls, given the prevalence of single sex independent schools and, hence, potential differences in this) in minutes. The third model (M3) also adds the travel time to the nearest Outstanding state school as a covariate. The fourth model (M4) instead adds travel time to the nearest Grammar school as a covariate. The fifth model (M5) is the same as M4 but additionally restricts the sample to pupils living in areas where a grammar school is deemed to be a feasible option, defined as areas in which any child attends a grammar school. In all cases, travel times are specified as linear and quadratic terms in the model to allow for the relationship to vary in a non-linear manner, given that once individuals are a long way from the nearest independent, outstanding, or grammar school further increases in travel time are likely to be less important.

We also repeat our modelling on alternative outcome variables based on attendance at a private school at different periods, allowing us to provide evidence on Hypothesis 5 regarding the relative importance of permanent and contemporary income to predicting private school attendance. Specifically, we model attendance at a private school 1) for primary school 2) for secondary school and 3 ) for secondary school conditional on attending a state primary school. These outcome measures are formally defined and referred to in the results tables as follows:

- Attend a private primary school (models begin with P): Indicator takes a value of 1 if private school is reported at 7 or 10 , and takes a value of 0 otherwise.

- Attend a private secondary school (models begin with S): Indicator takes a value of 1 if private school is reported at 14 , and takes a value of 0 otherwise.

- Private secondary school conditional on attending a state primary school (models begin with SP): Indicator takes a values of 1 if private school attendance is reported at age 14 and private school attendance is not reported at age 7 or 10, takes a values of 0 if state school attendance is reported at age 14 and private school attendance is not reported at either age 7 or 10 , and does not take a value otherwise.

The regression models for these alternative outcomes are slight variants of those used for modelling whether an individual ever attend private school, taking the form:

$y_{i} \quad=\alpha$

$+\beta_{1}$ Perm. Income (lower) $/$ week $_{\mathrm{i}}+\beta_{2}$ Perm. Income (upper) $/$ week $_{\mathrm{i}}$ 


$$
\begin{aligned}
& +\beta_{3} \text { Contemp. Income (lower) } / \text { week }_{i}+\beta_{4} \text { Contemp. Income (upper) } / \text { week }_{i} \\
& +\gamma \mathbf{X}_{\mathbf{i}}+\varepsilon_{i}
\end{aligned}
$$

where the additional term Contemp. Income is a measure of income at the sweep before the relevant decision point (again modelled as a piecewise linear function with a single kind to allow for a differential relationship below and within the top $10 \%$ of the income distribution, in the same way as the measure of permanent income).

In addition, we repeat the full set of models of ever attending a private school on the sample constituting the top $10 \%$ of the family income distribution (defined as the top $10 \%$ of permanent equivalised family income), in order to provide direct evidence on the factors that explain variation in private school attendance among those who would appear to have the financial resources to afford it (Hypothesis 6). These families have weekly equivalised income of at least $£ 526.37$. This model just includes a linear permanent income covariate (since clearly it would not be possible to estimate the relationship below the top $10 \%$ of the distribution among this sample). In view of the reduced sample size, we only explore whether individuals ever attend a private school.

Finally, we specify two additional models that address our Hypothesis 7 by attempting to capture family propensity to educate privately in a different manner using information on whether any of an individual's older siblings attends a private school. The sixth model (E6) begins by restricting the sample only to those with an older sibling (given potential sample selection effects from imposing this restriction) to act as a benchmark against which to judge the seventh model (E7) in which we add the older sibling attending private school covariate.

\section{Results}

\subsection{Descriptive analysis}

A cross tabulation of private school attendance in primary and secondary phases is reported in Table 1. This demonstrates that, within our sample, approximately $5 \%$ of parents report that their child attends a fee-paying primary school, while this rises to approximately $6 \%$ of parents reporting that their child attends a fee-paying secondary school. These figures are broadly in line with national trends at primary and lower secondary levels. However, our table illuminates that the broad aggregate stability disguises some churn between the sectors between the two phases: a fifth of those who attended a private primary school had switched to a state school for their secondary education, while $2.4 \%$ of those who attended a state primary school had switched to a private secondary school.

[Table 1 about here]

To understand these groups in greater detail, Table 2 describes the characteristics of these four possible configurations of private/state education at primary/secondary school, which we refer to as private/private (private schooling at both primary and secondary), private/state (private school for primary and state school or secondary), state/private (vice versa), and state/state (state schooling at both primary and secondary).

\section{[Table 2 about here]}

Perhaps unsurprisingly, according to Table 2, state/state attendees have the lowest average family income, while private/private attendees have the highest of the four groups. Parents who 'mix and match' fall somewhere between the two of these. Similar patterns are evident in terms of home ownership, as a proxy measure of financial wealth. Given the need to pay fees, it is unsurprising that family resources differ across these groups.

The first of these, which we refer to as 'liberal values', is (negatively) loaded on strongly by measures of concern about interracial schooling, neighbourhoods and relationships. There are essentially no differences in the average level of this factor associated with whether the responding 
parent's child goes on to attend private schools (if anything, these values are slightly higher among those who attend private schools). The second values measure, which we refer to as 'traditional values', is positively loaded on by measures associated with concerns regarding the impact on children and family life of mothers working. This is somewhat stronger among parents whose children go on to attend private schools. Finally, the third measure, which we refer to as 'education values', is positively loaded on by measures suggesting the importance of education for parenting and of learning. This is noticeably higher among parents of children who ever attend a private school.

Half of the analysis sample is female. This gender balance essentially does not differ between those who attend state schools throughout their educational career and those who attend private schools throughout. However, those who attend private secondary schools only are more likely to be female, while those who attend private primary schools only are more likely to be male. Pupils who ever attend a private school have higher average prior academic attainment (as measured by the Bracken School Readiness Score at age 5) than their peers who only ever attend a state school.

Previous evidence also suggests that the quality of locally available state schools is likely to be important for private school demand (Blundell et al., 2010), as is the availability of grammar schools. Those who attend a state school throughout their educational careers live closest to their nearest Outstanding school, while those who attend a private school throughout their educational career live furthest from one, with those who combine state and private education falling between these two. There is the same pattern with distance to the nearest grammar school, except that those who mix a private and state education are the group that live closest to a grammar school, consistent with the discussion above. It is notable that, among those who attend a private primary school before switching to a state secondary school, $37 \%$ actually go on to attend a grammar school, compared to just $4 \%$ of those who attended a state school throughout. This suggests that in many cases those we observe to 'mix and match', at least in this private primary/state secondary sequence, only do so where they judge the available state secondary school to be a good substitute for private schooling.

Older sibling private school attendance (which is only measured when an individual is aged 5) is highly correlated with whether the individual themselves attends private school (Table 3 ). Only $1 \%$ of those who never attend a private school have an older sibling who do so, while three quarters of those who attend a private school throughout primary and secondary school have an older sibling also attending private school. $60 \%$ of those who attend a private primary and a state secondary have an older sibling attending private school, while the figure is $9 \%$ of those who attend state primary and private secondary school. We can also consider this in a different way (Table 4): among those who have an older sibling $92 \%$ both attend a state school, $3.5 \%$ both attend a private school, and in $4.3 \%$ of cases one attends a private school but the other does not.

\section{[Table 3 about here]}

\section{[Table 4 about here]}

In this section, we have explored correlations between attendance at private school and both financial and non-financial factors. However, a number of these factors may well reflect other differences between the individuals in these groups and are likely to be highly correlated. We use multiple regression modelling to disentangle their associations with private school attendance.

\subsection{Regression modelling}

Results are reported as average marginal effects derived from the underlying probit regression models specified above. Our reporting concentrates particularly on the model of ever attending a private school, with reporting of subsequent outcomes focusing on the differences with the associations between characteristics and ever attending a private school. At the base of the results tables, the p-values from a test of joint significance of all values factors terms included in each relevant model, and from a test of the significance of the interaction between the traditional values measure and being in the top $10 \%$ of the income distribution (where relevant) are reported.

[Table 5 about here] 
Results from the analysis of attending a private primary school are reported in Table 5. Our first model (E0) highlights that increases in permanent family income are associated with increased probability of ever attending a private school with each additional $£ 100$ of equivalised income per week being associated with a $3 \%$ pt. increase in the probability of ever attending a private school across most of the income distribution and almost a $6 \%$ pt. increase within the top $10 \%$ of the income distribution, even though this model takes into account other potential predictors of private school participation.

Far from attenuating it, adding values factor scores to the model (E1) slightly strengthens, if anything, the association between family income and private school attendance (from a $3.1 \%$ pt. increase per $£ 100$ of weekly income to a 3.3\%pt. increase per $£ 100$ of weekly income across most of the income distribution). When it comes to the association between values themselves and private school attendance, a one standard deviation increase in parents' traditional values is associated with approximately a $2.5 \%$ pt. increase in the probability of their child ever attending a private school, while a one standard deviation increase in parents' education values is associated with around a $1 \%$ pt. increase. Liberal values are not statistically significantly associated with private school attendance.

[Figure 1 about here]

As it is difficult to interpret interactions in models of non-linear outcomes, to report the results of model E2 we make use of a plot of predicted probabilities in which most characteristics are held constant, while the covariates in our interaction of interest are allowed to vary. This plot is shown in Figure 1 in which income is held constant at two illustrative levels (the median and the top decile) while our traditional values factor varies. The slope associated with family values is greater at the top decile than it is at the median.

Our next models (E3 and E4) include information on the distance to private schools and what we argue are seen as state-school substitutes. We find that each minute in increased travel time to a private school is associated with $0.4 \%$ pt. lower rates of attendance at private school, while each minute of increased travel time to an outstanding school is associated with $0.2 \%$ pt. higher rates of attendance at private schools. Similarly, increased travel time to the nearest grammar school is linked with higher rates of private school attendance (E4), while this association is strengthened when we restrict attention to areas in which grammar schools are a feasible option (E5). These associations are on top of those explained by family income and values, which are not much attenuated.

[Table 6 about here]

\section{[Table 7 about here]}

The results from our models of attending a private primary school and of attending a private secondary school are reported respectively in Tables 6 and 7. Both tables show that permanent income is substantially more important in predicting private school attendance than contemporary income at the time when individuals start each phase of schooling. In the case of secondary schooling, there is more of a role for contemporary income than is the case with primary schooling, perhaps reflecting the higher fees, although only at the top of the income distribution. However, these associations are still smaller than those for permanent income. Traditional values retain a strong association with private school attendance at both primary and secondary levels.

\section{[Table 8 about here]}

The analysis of transition from a state primary school to a private secondary school is reported in Table 8. In this model, current income is much more important than permanent income, likely because the role of permanent income is captured by the fact that we have restricted the sample only to those who did not attend a private primary school. Increasing levels of income among those in the top $10 \%$ of the income distribution are associated with higher probabilities of making a transition from a state primary to a private secondary school. 
[Table 9 about here]

Results from an analysis of ever attending a private school among the sample restricted to those in the top $10 \%$ of the family income distribution are reported in Table 9 . The strength of the association with distance to an Outstanding school is no weaker among this group, although it is no longer significant at the 5\% level due to the reduced sample size. Demand for private schooling is still significantly positively associated with travel time to grammar schools.

Analyses of models exploring the informational value of older siblings' private school attendance are reported in Table 10. This includes a baseline model (E5), a model restricting only to the sample with an older sibling (E6), which does not affect the associations we observe, and the model of interest adding in the indicator of older siblings' private school attendance (E7), which attenuates the associations between private school attendance and both family income at the top of the income distribution and parental values by approximately half. Furthermore, the older sibling private school attendance indicator itself is associated with a $15 \%$ pt. increase in the probability of private school attendance.

[Table 10 about here]

\section{Discussion and Conclusions}

In this paper, we have conducted new analyses of a rich, longitudinal dataset from a recent, representative birth cohort study, to provide new evidence on the predictors of participation in private schooling. These results contribute to the understanding of the motivations of those who send their children to private schools, including demonstrating the relevance of parental values and an important interplay between the availability of well-regarded state schooling in an area and demand for private schooling.

We, for the first time, explore the transitions between state and private sectors between primary and secondary phases. Our findings demonstrates the underappreciated prevalence of families who send their children to a private school for the primary phase of education, but not the secondary phase, or vice versa: a fifth of those who attended a private primary school had switched to a state school for their secondary education; $2.4 \%$ of those who attended a state primary school had switched to a private school for their secondary education. Comparing the characteristics of those who 'mix and match' with those whose children remain in private schools throughout, there is similarity in terms of family values but difference in terms of financial resources, suggesting a possible reason for economising at one phase to afford private education during the other. This provides partial support for Hypothesis 1 in that there are differences in family finances, but not in family values.

Our regression modelling allows us to explore the interplay of the factors we consider. Our results indicate that, while family income is important as a predictor of sending a child to private school, it should not be considered in isolation. There is an important role for parental values, something earlier analyses have not included (Dearden et al., 2011) or have not quantified (Ball, 1997). In particular, we find evidence that parental traditional values and education values are important in predicting attendance at a private school, and that this is the case over and above the role of income. One interpretation could be that this measure of traditional values is capturing a proxy for parents' political views and attitudes towards equality. Both by allowing the association between traditional values and private schooling to vary across the income distribution, and separately exploring predictors of private schooling only among those in the top $10 \%$ of the income distribution, we find that traditional values appear to play a role that is particularly important in explaining the remaining variation in attendance evident within the top $10 \%$ of the income distribution (Henseke et al., nd), perhaps unsurprisingly given that finance is less likely to be a binding constraint here. Taken together this picture provides support for Hypothesis 2.

Newly derived data also allow us to explore the importance of travel time to private schools and substitutes for these, in the shape of both state-funded schools judged 'Outstanding' by England's education inspectorate and academically selective state-funded schools. We find evidence that 10 minutes of reduced travel time to the nearest private school is associated with $4 \%$ pts. increased attendance at a private school; conversely, 10 minutes of reduced travel time to an 'Outstanding' state 
school is associated with $2 \%$ pts. lower rates of private schooling. These relationships are over and above the other background characteristics we have considered, notably parental values and family income. These findings support Hypotheses 3 and 4, and provide suggestive evidence that, at least for some parents who might otherwise choose to send their children to private schools, certain state schools can provide the environment they are seeking.

When considering income, we note the important distinction between permanent and contemporary income when starting primary and secondary phases of schooling in predicting private school attendance. In line with established findings from the economics literature on educational investment (Blau, 1999; Chevalier et al., 2013; Carneiro and Ginja, 2016), we find that permanent income is more important than contemporary income at the start of either primary or secondary school in predicting private school attendance in each of these phases, in line with Hypothesis 5. However, we also note the role of contemporary income near the top of the income distribution in predicting private secondary school attendance, perhaps due to the higher fees demanded for this phase than by private primary schools. Furthermore, we find that among those near the top of the income distribution, greater contemporary income at the point of transition between primary and secondary phases predicts movement from a state to a private school at this point (whereas we do not see this for permanent income when considering this transition). Moreover, by comparing the strength of the association between family income and private school attendance in our general model, and in our model including only those at the top of the income distribution, we find support for Hypothesis 6 that additional family income is a stronger predictor among those with already high levels of income, consistent with affordability constraints lower down the income distribution.

Finally, confirming Hypothesis 7, we find evidence that older sibling private school attendance captures a highly predictive revealed preference among parents for sending their offspring to a private school. The relationship is present conditional on the other associations found in our modelling, suggesting this family-level propensity to education privately is not entirely captured by the other observed characteristics that we have included in our modelling approach. Furthermore, the presence of this factor in the modelling does attenuate the relationship between private schooling and both family income among those with high levels of income and family traditional values, suggesting these form an important component of this underlying family-level propensity.

There are inevitably limitations in our analysis. While the dataset used is incredibly rich in detail about participants and their families, it is still the case that not all potential factors relevant to predicting private school attendance are measures (or, indeed, measurable). Since our empirical approach relies on controlling for such factors to isolate the relationship with private school attendance attributable to our factors of interest, we caution that no relationship should be considered causal, but rather suggestive of an underlying relationship which may be amenable to further investigation to isolate its specific role. Furthermore, like all surveys, there may be issues with representativeness, especially as a result of nonrandom attrition from the sample over the course of the study. We attempt to mitigate this using the study-provided design and non-response weights, but these will be unable to adjust for attrition associated with unobserved factors.

Nevertheless, this analysis sheds light on underappreciated aspects of the motivations of those who send their children to private school. Its implications are primarily for those seeking a nuanced understanding of such relationships as the basis for further investigation, for example of the educational and labour market outcomes associated with attending a private school, which will benefit from being aware of some of the key differences between those who attend private school and those who do not beyond the simple differences in their family's financial resources. It may also have implications for those seeking to understand competition between state and private education sectors and the circumstances under which this occurs.

\section{Acknowledgements}

We are grateful to UKRI Economic and Social Research Council for supporting this research under its Secondary Data Analysis Initiative (ES/R003335/1). Dr Anders' time was also partially supported by the UCL Centre for Education Policy and Equalising Opportunities. Thanks to Gabriela Melis for advice on the construction and interpretation of the values measures. Thank you also to David Church at the UCL Centre for Longitudinal Studies for constructing the travel time measures. Thanks to UK Data Service Secure Lab team for 
their assistance with data access. We are grateful for the support for the Centre for Research on Learning and Life Chances (LLAKES) for help in coordinating the 'Private Schools in the $21^{\text {st }}$ Century' workshop held in December 2018. We would also like to acknowledge the contribution from those who participated in this workshop who provided valuable comments.

\section{Data Availability Statement}

This data that support the findings of this study (the Millennium Cohort Study, MCS) is openly available from the UK Data Service (University of London. Institute of Education. Centre for Longitudinal Studies, 2017a-f, 2018). The newly derived data on distance to independent and 'well-regarded' state schools may not be available at time of publication but will be included in a future update to the dataset.

\section{Ethics Statement}

This project was carried out under the British Educational Research Association's Ethical Guidelines and was approved through the prescribed process set out by the UCL Institute of Education Ethics Committee (REC 1001).

\section{Disclosure Statement}

No potential conflict of interest was reported by the authors.

\section{Bibliography}

Acemoglu, D. and Pischke, J. S. (2001). Changes in the wage structure, family income, and children's education. European Economic Review, 45(4-6):890-904. doi :10 .1016/s 0014 2921 ( 01 ) $00115-5$.

Allen, R. and Burgess, S. (2013). Evaluating the provision of school performance information for school choice. Economics of Education Review, 34:175-190.

doi:10.1016/j.econedurev.2013.02.001.

Ball, Stephen, J. (1997). On the cusp: parents choosing between state and private schools in the UK: action within an economy of symbolic goods. International Journal of Inclusive Education, 1(1):1-17.

Ball, Stephen, J., Bowe, R., and Gewirtz, S. (1997). School choice, social class and distinction: the realization of social advantage in education. Journal of Education Policy, 11(1):89-112.

doi : $10.1080 / 0268093960110105$.

Becker, G. S. and Tomes, N. (1986). Human-capital and the rise and fall of families. Journal of Labor Economics, 4(3):S1-S39.

Belfield, C., Britton, J., Buscha, F., Dearden, L., Dickson, M., van der Erve, L., Sibieta, L., Vignoles, A., Walker, I., and Zhu, Y. (2018). The relative labour market returns to different degrees. DfE Research Report DFE-RR787, Department for Education.

Blau, D. M. (1999). The effect of income on child development. The Review of Economics and Statistics, 81(2):261-276. doi:10.1162/003465399558067.

Blow, L., Blundell, R., Machin, S., and Sibieta, L. (2011). The demand for private schooling in the UK: The role of income and inequality. IFS Working Paper 11/13, Institute for Fiscal Studies. Blundell, R., Dearden, L., and Sibieta, L. (2010). The demand for private schooling: the impact of price and quality. IFS Working Paper 10/21, Institute for Fiscal Studies.

Burgess, S., Greaves, E., and Vignoles, A. (2019). School choice in England: evidence from national administrative data. Oxford Review of Education. doi : 10.1080/03054985.2019.1604332.

Burgess, S., Greaves, E., Vignoles, A., and Wilson, D. (2014). What parents want: school preferences and school choice. The Economic Journal, 125(587):1262-1289. doi : 10 . 1111 / ecoj .12153.

Carneiro, P. and Ginja, R. (2016). Partial insurance and investments in children. Economic Journal, 126(596):F66-F95. doi:10.1111/ecoj.12421.

Chevalier, A., Harmon, C., O'Sullivan, V., and Walker, I. (2013). The impact of parental income and education on the schooling of their children. IZA Journal of Labor Economics, 2(1):1-22.

doi: $10.1186 / 2193-8997-2-8$.

Church, D. (2018). MCS 4 \& MCS 5: Distances and 45 minute drive-times to high-performing schools in England. CLS Data Note, Centre for Longitudinal Studies, UCL Institute of Education. 
Crawford, C., Gregg, P., Macmillan, L., Vignoles, A., and Wyness, G. (2016). Higher education, career opportunities, and intergenerational inequality. Oxford Review of Economic Policy, 32(4):553-575.

doi:10.1093/oxrep/grw030.

Dearden, L., Ferri, J., and Meghir, C. (2002). The effect of school quality on educational attainment and wages. Review of Economics and Statistics, 81(1):1-20. doi :10.1162/003465302317331883.

Dearden, L., Ryan, C., and Sibieta, L. (2011). What Determines Private School Choice? A Comparison between the United Kingdom and Australia. Australian Economic Review, 44(3):308-320.

doi:10.1111/j.1467-8462.2011.00650.x.

Department for Education (2018). Schools, pupils, and their characteristics: January 2018. DfE Statistical First Release, Department for Education.

Foskett, N. and Hemsley-Brown, J. (2003). Economic aspirations, cultural replication and social dilemmas: interpreting parental choice of British private schools. In Walford, G., editor, British Private Schools: Research on policy and practice, pages 188-201. Woburn Press, London.

Fox, I. (1985). Private Schools and Public Issues: The Parents' View. Macmillan, London.

Gibbons, S., Machin, S., and Silva, O. (2013). Valuing school quality using boundary discontinuities.

Journal of Urban Economics, 75:15-28. doi:10.1016/j · jue.2012.11.001.

Gorard, S. (1999). 'Well. That about wraps it up for school choice research': A state of the art review. School Leadership and Management, 19(1):25-47. doi:10.1080/13632439969320.

Green, F., Anders, J., Henderson, M., and Henseke, G. (2018). Who Chooses Private Schooling in Britain and Why? LLAKES Research Paper 62, LLAKES Centre for Learning and Life Chances in Knowledge Economies and Societies, UCL Institute of Education.

Green, F., Henseke, G., and Vignoles, A. (2017). Private schooling and labour market outcomes. British Educational Research Journal, 43(1):7-28. doi : 10 .1002/berj . 3256.

Green, F. and Kynaston, D. (2019). Engines of Privilege: Britain's Private School Problem. Bloomsbury, London.

Green, F., Machin, S., Murphy, R., and Zhu, Y. (2012). The changing economic advantage from private schools. Economica, 79(316):658-679. doi:10.1111/j.1468-0335.2011.00908.x.

Henseke, G., Anders, J., Green, F., and Henderson, M. (n.d.). The income and wealth concentration of private school attendance in Britain. Under review.

Hu, L. T. and Bentler, P. M. (1999). Cutoff criteria for fit indexes in covariance structure analysis:

Conventional criteria versus new alternatives. Structural Equation Modeling. A Multidisciplinary Journal, 6:1-55. doi:10.1080/10705519909540118.

Independent Schools Council (2018). ISC Census and Annual Report. ISC Report, Independent Schools Council.

Kolenikov, S. and Angeles, G. (2009). Socioeconomic status measurement with discrete proxy variables: Is principal component analysis a reliable answer? Review of Income and Wealth, 55(1):128-165.

doi:10.1111/j.1475-4991.2008.00309.x.

Little, R. and Rubin, D. (1989). The analysis of social science data with missing values. Sociological Methods \& Research, 18(2-3):292-326. doi : 10.1177/0049124189018002004.

Machin, S. (2011). Houses and schools: Valuation of school quality through the housing market. Labour Economics, 18:723-729. doi:j.labeco.2011.05.005.

Macmillan, L., Tyler, C., and Vignoles, A. (2015). Who gets the top jobs? the role of family background and networks in recent graduates' access to high-status professions. Journal of Social Policy, 44(3):487515. doi:10.1017/S0047279414000634.

Maxwell, C. and Aggleton, P. (2015). Elite Education: International Perspectives. Routledge, London. doi: $10.4324 / 9781315755984$.

Noakes, B. (2015). Mix and match state and private education. Web page, The Good Schools Guide.

Retrieved from https://www.goodschoolsguide.co.uk/archive/choosing-a-school/mix-and-match-state-andprivate-education on 22/11/2017.

Parsons, S., Green, F., Ploubidis, G., Sullivan, A., and Wiggins, R. (2017). The influence of private primary schooling on children's learning: Evidence from three generations of children living in the UK. British Educational Research Journal, 43(5):823-847. doi : 10.1002 / berj . 3300.

Reeves, A., Friedman, S., Rahal, C., and Flemmen, M. (2017). The decline and persistence of the old boy: Private schools and elite recruitment 1897 to 2016. American Sociological Review, 82(6):1139-1166. doi : $10.1177 / 0003122417735742$.

Sullivan, A. and Heath, A. (2003). Intakes and examination results at state and private schools. In Walford, G., editor, British Private Schools: Research on policy and practice, pages 77-104. Woburn Press, London. 
Sullivan, A., Parsons, S., Wiggins, R., Heath, A., and Green, F. (2014). Social origins, school type and higher education destinations. Oxford Review of Education, 40(6):739-763.

doi: $10.1080 / 03054985.2014 .979015$.

[dataset] University of London. Institute of Education. Centre for Longitudinal Studies (2017a).

Millennium cohort study: Fifth survey, 2012. [data collection]. 4th Edition. UK Data Service. SN: 7464.

http://doi .org/10.5255/UKDA-SN-7464-4.

[dataset] University of London. Institute of Education. Centre for Longitudinal Studies (2017b).

Millennium cohort study: First survey, 2001-2003. [data collection]. 12th Edition. UK Data Service. SN:

4683. http: //doi.org/10.5255/UKDA-SN-4683-4.

[dataset] University of London. Institute of Education. Centre for Longitudinal Studies (2017c).

Millennium cohort study: Fourth survey, 2008. [data collection]. 7th Edition. UK Data Service. SN: 6411.

http: / / doi .org/10.5255/UKDA-SN-6411-7.

[dataset] University of London. Institute of Education. Centre for Longitudinal Studies (2017d).

Millennium cohort study: Longitudinal family file, 2001-2015. [data collection]. 2nd Edition. UK Data

Service. SN: 8172. http: / / doi.org/10.5255/UKDA-SN-8172-2.

[dataset] University of London. Institute of Education. Centre for Longitudinal Studies (2017e).

Millennium cohort study: Second survey, 2003-2005. [data collection]. 9th Edition. UK Data Service. SN:

5350. http: //doi.org/10.5255/UKDA-SN-5350-4.

[dataset] University of London. Institute of Education. Centre for Longitudinal Studies (2017f).

Millennium cohort study: Third survey, 2006. [data collection]. 7th Edition. UK Data Service. SN: 5795.

http://doi.org/10.5255/UKDA-SN-5795-4.

[dataset] University of London. Institute of Education. Centre for Longitudinal Studies (2018).

Millennium cohort study: Sixth survey, 2015. [data collection]. 3rd Edition. UK Data Service. SN: 8156.

http: / /doi.org/10.5255/UKDA-SN-8156-3.

West, A., Noden, P., Edge, A., David, M., and Davies, J. (1998). Choices and expectations at primary and secondary stages in the state and private sectors. Educational Studies, 24(1):45-60.

doi: $10.1080 / 0305569980240103$.

Whitty, G., Power, S., and Edwards, T. (1998). The assisted places scheme: Its impact and its role in privatization and marketization. Journal of Education Policy, 13(2):237-250.

doi:10.1080/0268093980130205.

Wilde, R., Green, F., Taylor-Gooby, P., and Wiborg, S. (2016). Private schools and the provision of “public benefit". Journal of Social Policy, 45(2):305-323. doi:10.1017/ S0 047279415000719.

Supplementary Information linked to the online version of the paper:

- Values Measures methodological supplement 
Table 1: Transition matrix between primary and secondary state and independent schools

\begin{tabular}{lrrr} 
& \multicolumn{3}{c}{ Secondary School } \\
Primary School & State & Private & Total \\
& $\%$ & $\%$ & $\%$ \\
\hline State & 97.6 & 2.4 & 100.0 \\
Private & 20.5 & 79.5 & 100.0 \\
Total & 93.9 & 6.1 & 100.0 \\
\hline \hline
\end{tabular}

Notes. Source: University of London. Institute of Education. Centre for Longitudinal Studies (2017b, 2017e, 2017f, 2017c, 2017a, 2018, 2017d). Analysis accounts for MCS survey design and MCS-supplied sampling and non-response weights. Reporting weighted row means. 
Table 2: Descriptive Statistics

\begin{tabular}{lrrrrr} 
Variable & State & Combination & Private & Overall & SD \\
\hline Perm. Equiv. Family Income (£/wk.) & 298.01 & 449.31 & 562.51 & 312.93153 .52 \\
Own House & 0.64 & 0.86 & 0.94 & 0.66 & 0.47 \\
Liberal Values Z-Score & -0.00 & 0.08 & 0.02 & 0.00 & 1.00 \\
Trad. Values Z-Score & -0.01 & 0.19 & 0.18 & -0.00 & 1.00 \\
Edu. Values Z-Score & -0.03 & 0.36 & 0.35 & 0.00 & 1.00 \\
Female & 0.50 & 0.52 & 0.49 & 0.50 & 0.50 \\
Bracken School Readiness Score & -0.02 & 0.42 & 0.54 & 0.02 & 0.93 \\
Attend Grammar School & 0.05 & 0.11 & 0.00 & 0.05 & 0.21 \\
Travel Time to nearest Independent school (mins) & 11.37 & 9.30 & 9.74 & 11.25 & 7.39 \\
Travel Time to nearest Grammar School (mins) & 32.31 & 29.09 & 33.26 & 32.24 & 22.38 \\
Travel Time to nearest Outstanding school (mins) & 10.62 & 10.21 & 11.81 & 10.65 & 7.48 \\
Older Sib. Private & 0.01 & 0.20 & 0.75 & 0.05 & 0.21 \\
\hline $\mathrm{N}$ & 5395 & 196 & 218 & 5809 &
\end{tabular}

Notes. Source: University of London. Institute of Education. Centre for Longitudinal Studies (2017b, 2017e, 2017f, 2017c, 2017a, 2018, 2017d). Analysis accounts for MCS survey design and MCS-supplied sampling and non-response weights. Reporting weighted cell means, overall weighted standard deviations (SDs), and unweighted group counts (Ns). Sample size reduced to 3,167 for proportion of older sibling attending private school due to need to restrict sample to those with an older sibling. 
Table 3: Older Siblings and Private School

Primary/Secondary School Type

Mean

Prop. Older Sib. Attends Private School

State

0.01

Combination

0.20

Private

0.75

Total

0.05

Notes. Source: University of London. Institute of Education. Centre for Longitudinal Studies (2017b, 2017e, 2017f, 2017c, 2017a, 2018, 2017d). Compared to analysis in Table 1, sample size reduced to 3,167 due to need to restrict sample to those with an older sibling. Analysis accounts for MCS survey design and MCS-supplied sampling and non-response weights. Reporting weighted cell means. 
Table 4: Private School attendance among those with older siblings

Cohort member/older sibling school type

State/State

$\%$

Private/State

State/Private

3.1

Private/Private

3.5

Total

100.0

Notes. Source: University of London. Institute of Education. Centre for Longitudinal Studies (2017b, 2017e, 2017f, 2017c, 2017a, 2018, 2017d). Compared to analysis in Table 1, sample size reduced to 3,167 due to need to restrict sample to those with an older sibling. Analysis accounts for MCS survey design and MCS-supplied sampling and non-response weights. Reporting weighted cell means. 
Table 5: Average marginal effects on probability of ever attending a private school

\begin{tabular}{|c|c|c|c|c|c|c|}
\hline & E0 & E1 & E2 & E3 & E4 & E5 \\
\hline Perm. Fam. Inc. (lower) / £100/wk. & $\begin{array}{c}0.0305^{* * *} \\
(5.46)\end{array}$ & $\begin{array}{c}0.0328 * * * \\
(5.95)\end{array}$ & $\begin{array}{c}0.0319 * * * \\
(6.09)\end{array}$ & $\begin{array}{c}0.0327 * * * \\
(6.33)\end{array}$ & $\begin{array}{c}0.0328 * * * \\
(6.35)\end{array}$ & $\begin{array}{c}0.0335 * * * \\
(5.05)\end{array}$ \\
\hline Perm. Fam. Inc. (upper) / £100/wk. & $\begin{array}{c}0.0580 * * *( \\
(9.10)\end{array}$ & $\begin{array}{c}0.0587 * * *( \\
\quad(9.61)\end{array}$ & $\begin{array}{c}0.0603 * * * \\
(9.36)\end{array}$ & $\begin{array}{c}0.0577 * * * \\
(9.52)\end{array}$ & $\begin{array}{c}0.0581^{* * * *} \\
\quad(9.50)\end{array}$ & $\begin{array}{c}0.0594 * * * \\
(6.49)\end{array}$ \\
\hline Female & $\begin{array}{c}0.00261 \\
(0.49)\end{array}$ & $\begin{array}{c}0.000429 \\
(0.08)\end{array}$ & $\begin{array}{c}-0.000207 \\
(-0.04)\end{array}$ & $\begin{array}{c}-0.00149 \\
(-0.28)\end{array}$ & $\begin{array}{c}-0.00123 \\
(-0.23)\end{array}$ & $\begin{array}{c}-0.00864 \\
(-1.15)\end{array}$ \\
\hline Housing: Own & $\begin{array}{c}0.0154 \\
(1.39)\end{array}$ & $\begin{array}{l}0.0128 \\
(1.19)\end{array}$ & $\begin{array}{l}0.0127 \\
(1.20)\end{array}$ & $\begin{array}{c}0.00972 \\
(0.89)\end{array}$ & $\begin{array}{c}0.0110 \\
(1.00)\end{array}$ & $\begin{array}{c}0.00312 \\
(0.19)\end{array}$ \\
\hline Bracken School Readiness Z-Score & $\begin{array}{c}0.0104 * \\
(2.41)\end{array}$ & $\begin{array}{c}0.0106^{*} \\
(2.49)\end{array}$ & $\begin{array}{c}0.0104 * \\
(2.49)\end{array}$ & $\begin{array}{c}0.00884^{*} \\
(2.19)\end{array}$ & $\begin{array}{c}0.00974^{*} \\
(2.38)\end{array}$ & $\begin{array}{c}0.0131^{*} \\
(2.38)\end{array}$ \\
\hline Liberal Values Z-Score & & $\begin{array}{c}0.00295 \\
(0.88)\end{array}$ & $\begin{array}{c}0.00305 \\
(0.91)\end{array}$ & $\begin{array}{c}0.00201 \\
(0.60)\end{array}$ & $\begin{array}{c}0.00171 \\
(0.52)\end{array}$ & $\begin{array}{c}0.00708 \\
(1.44)\end{array}$ \\
\hline Trad. Values Z-Score & & $\begin{array}{c}0.0241 * * * \\
(6.53)\end{array}$ & $\begin{array}{c}0.0247 * * * \\
(7.03)\end{array}$ & $\begin{array}{c}0.0237 * * * \\
(7.05)\end{array}$ & $\begin{array}{c}0.0234 * * * \\
(6.92)\end{array}$ & $\begin{array}{c}0.0281 * * * \\
(6.00)\end{array}$ \\
\hline Edu. Values Z-Score & & $\begin{array}{c}0.00923 * \\
(2.50)\end{array}$ & $\begin{array}{c}0.00949 * \\
(2.55)\end{array}$ & $\begin{array}{c}0.00867 * \\
(2.41)\end{array}$ & $\begin{array}{c}0.00871^{*} \\
(2.37)\end{array}$ & $\begin{array}{c}0.00714 \\
(1.40)\end{array}$ \\
\hline Travel Time to Independent school / 10 mins & & & & $\begin{array}{c}-0.0398 * * * \\
(-4.79)\end{array}$ & $\begin{array}{c}-0.0344 * * * \\
(-4.58)\end{array}$ & $\begin{array}{c}-0.0383 * * * \\
(-3.68)\end{array}$ \\
\hline Travel Time to Outstanding School / 10 mins & & & & $\begin{array}{c}0.0217^{* *} \\
(3.23)\end{array}$ & & \\
\hline Travel Time to Grammar School / 10 mins & & & & & $\begin{array}{c}0.00650 * * \\
\quad(3.27)\end{array}$ & $\begin{array}{c}0.0199 * * * \\
(3.92)\end{array}$ \\
\hline Region & $\sqrt{ }$ & $\sqrt{ }$ & $\sqrt{ }$ & $\sqrt{ }$ & $\sqrt{ }$ & $\sqrt{ }$ \\
\hline$\overline{\mathrm{N}}$ & 5809 & 5809 & 5809 & 5803 & 5803 & 3314 \\
\hline $\mathrm{p}$ valu & r & 0.00 & 0.00 & 0.00 & 0.00 & 0.00 \\
\hline $\mathrm{p}$ value of $\mathrm{F}$ te & & & 0.04 & 0.04 & 0.04 & 0.06 \\
\hline Residual Degrees of Freedom & 197 & 197 & 197 & 197 & 197 & 174 \\
\hline
\end{tabular}

Notes. Source: University of London. Institute of Education. Centre for Longitudinal Studies (2017b, 2017e, 2017f, 2017c, 2017a, 2018, 2017d). Analysis takes into account survey design and is weighted using MCS-supplied sampling and nonresponse weights. Models Ns are unweighted. Reporting average marginal effects based on underlying probit regression model. School type measurement based on parental reports when cohort member is aged 7, 10 and 14. $\mathrm{t}$ statistics in parentheses: * $p<0.05, * * p<0.01, * * * p<0.001$. Omitted categories are as follows: Housing: Rent or Other; Gender: male. 
Table 6: Average marginal effects on probability of attending a private primary school

\begin{tabular}{|c|c|c|c|c|c|c|}
\hline & $\mathrm{P} 0$ & $\mathrm{P} 1$ & $\mathrm{P} 2$ & $\mathrm{P} 3$ & $\mathrm{P} 4$ & P5 \\
\hline Age 5 Fam. Inc. (lower) / £100/wk. & $\begin{array}{c}-0.00905^{*} \\
(-2.51)\end{array}$ & $\begin{array}{c}-0.00835^{*} \\
(-2.42)\end{array}$ & $\begin{array}{c}-0.00817 * \\
(-2.42)\end{array}$ & $\begin{array}{c}-0.00772 * \\
(-2.30)\end{array}$ & $\begin{array}{c}-0.00773 * \\
(-2.29)\end{array}$ & $\begin{array}{c}-0.0105^{*} \\
(-2.41)\end{array}$ \\
\hline Age 5 Fam. Inc. (upper) /£100/wk. & $\begin{array}{c}0.00594 \\
(1.51)\end{array}$ & $\begin{array}{c}0.00574 \\
(1.48)\end{array}$ & $\begin{array}{c}0.00601 \\
(1.53)\end{array}$ & $\begin{array}{c}0.00506 \\
(1.30)\end{array}$ & $\begin{array}{c}0.00513 \\
(1.33)\end{array}$ & $\begin{array}{c}0.00713 \\
(1.49)\end{array}$ \\
\hline Perm. Fam. Inc. (lower) /£100/wk. & $\begin{array}{c}0.0338 * * * \\
(4.51)\end{array}$ & $\begin{array}{c}0.0339 * * * \\
(4.70)\end{array}$ & $\begin{array}{c}0.0325 * * * \\
(4.72)\end{array}$ & $\begin{array}{c}0.0326 * * * \\
(4.81)\end{array}$ & $\begin{array}{c}0.0329 * * * \\
(4.77)\end{array}$ & $\begin{array}{c}0.0387 * * * \\
(4.52)\end{array}$ \\
\hline Perm. Fam. Inc. (upper) /£100/wk. & $\begin{array}{c}0.0351 * * * \\
(5.43)\end{array}$ & $\begin{array}{c}0.0359 * * * \\
(5.59)\end{array}$ & $\begin{array}{c}0.0364 * * * \\
(5.68)\end{array}$ & $\begin{array}{c}0.0362 * * * \\
\quad(5.58)\end{array}$ & $\begin{array}{c}0.0363 * * * \\
(5.69)\end{array}$ & $\begin{array}{c}0.0325 * * * \\
\quad(3.75)\end{array}$ \\
\hline Female & $\begin{array}{c}-0.00182 \\
(-0.38)\end{array}$ & $\begin{array}{c}-0.00323 \\
(-0.64)\end{array}$ & $\begin{array}{c}-0.00423 \\
(-0.84)\end{array}$ & $\begin{array}{c}-0.00533 \\
(-1.08)\end{array}$ & $\begin{array}{c}-0.00500 \\
(-1.00)\end{array}$ & $\begin{array}{c}-0.0106 \\
(-1.44)\end{array}$ \\
\hline Housing: Own & $\begin{array}{c}0.00397 \\
(0.42)\end{array}$ & $\begin{array}{c}0.00305 \\
(0.33)\end{array}$ & $\begin{array}{c}0.00317 \\
(0.35)\end{array}$ & $\begin{array}{c}0.00119 \\
(0.13)\end{array}$ & $\begin{array}{c}0.00159 \\
(0.17)\end{array}$ & $\begin{array}{c}-0.00134 \\
(-0.11)\end{array}$ \\
\hline Bracken School Readiness Z-Score & $\begin{array}{c}0.00906^{* *} \\
(2.62)\end{array}$ & $\begin{array}{c}0.00902 * * \\
(2.64)\end{array}$ & $\begin{array}{c}0.00892 * * \\
(2.68)\end{array}$ & $\begin{array}{c}0.00732 * \\
(2.30)\end{array}$ & $\begin{array}{c}0.00811 * \\
(2.47)\end{array}$ & $\begin{array}{c}0.0111^{*} \\
(2.33)\end{array}$ \\
\hline Liberal Values Z-Score & & $\begin{array}{c}0.000476 \\
(0.18)\end{array}$ & $\begin{array}{c}0.000586 \\
(0.22)\end{array}$ & $\begin{array}{c}-0.0000170 \\
(-0.01)\end{array}$ & $\begin{array}{c}-0.000207 \\
(-0.08)\end{array}$ & $\begin{array}{c}0.00436 \\
(1.11)\end{array}$ \\
\hline Trad. Values Z-Score & & $\begin{array}{c}0.0146^{* * * *} \\
(4.61)\end{array}$ & $\begin{array}{c}0.0154^{* * * *} \\
(5.29)\end{array}$ & $\begin{array}{c}0.0149 * * * \\
(5.21)\end{array}$ & $\begin{array}{c}0.0147^{* * * *} \\
(5.14)\end{array}$ & $\begin{array}{c}0.0190 * * * \\
\quad(4.57)\end{array}$ \\
\hline Edu. Values Z-Score & & $\begin{array}{c}0.00647 * \\
(2.33)\end{array}$ & $\begin{array}{c}0.00677 * \\
(2.41)\end{array}$ & $\begin{array}{c}0.00610^{*} \\
(2.25)\end{array}$ & $\begin{array}{c}0.00604^{*} \\
(2.20)\end{array}$ & $\begin{array}{c}0.00375 \\
(0.91)\end{array}$ \\
\hline Travel Time to Independent school /10 mins & & & & $\begin{array}{c}-0.0245^{* * * *} \\
(-3.83)\end{array}$ & $\begin{array}{c}-0.0204 * * * \\
(-3.55)\end{array}$ & $\begin{array}{c}-0.0244 * * \\
(-2.75)\end{array}$ \\
\hline Travel Time to Outstanding School / 10 mins & & & & $\begin{array}{c}0.0148^{* *} \\
(2.76)\end{array}$ & & \\
\hline Travel Time to Grammar School / 10 mins & & & & & $\begin{array}{c}0.00389^{*} \\
(2.33)\end{array}$ & $\begin{array}{c}0.0129^{* *} \\
(3.12)\end{array}$ \\
\hline$\underline{\text { Region }}$ & $\sqrt{ }$ & $\sqrt{ }$ & $\sqrt{ }$ & $\sqrt{ }$ & $\sqrt{ }$ & $\sqrt{ }$ \\
\hline$\overline{\mathrm{N}}$ & 5809 & 5809 & 5809 & 5803 & 5803 & 3314 \\
\hline$p$ value of $F$ test of values & $\cdot$ & 0.00 & 0.00 & 0.00 & 0.00 & 0.00 \\
\hline $\mathrm{p}$ value of $\mathrm{F}$ test of trad. values/income interaction & & & 0.01 & 0.01 & 0.01 & 0.05 \\
\hline Residual Degrees of Freedom & 197 & 197 & 197 & 197 & 197 & 174 \\
\hline
\end{tabular}

Notes. Source: University of London. Institute of Education. Centre for Longitudinal Studies (2017b, 2017e, 2017f, 2017c, 2017a, 2018, 2017d). Analysis takes into account survey design and is weighted using MCS-supplied sampling and nonresponse weights. Models Ns are unweighted. Reporting average marginal effects based on underlying probit regression model. School type measurement based on parental reports when cohort member is aged 7, 10 and 14. $\mathrm{t}$ statistics in parentheses: * $p<0.05, * * p<0.01, * * * p<0.001$. Omitted categories are as follows: Housing: Rent or Other; Gender: male. 
Table 7: Average marginal effects on probability of attending a private secondary school

\begin{tabular}{|c|c|c|c|c|c|c|}
\hline & S0 & S1 & S2 & S3 & S4 & S5 \\
\hline Age 10 Fam. Inc. (lower) / £100/wk. & $\begin{array}{c}0.000389 \\
(0.10)\end{array}$ & $\begin{array}{c}0.000776 \\
(0.22)\end{array}$ & $\begin{array}{c}0.000833 \\
(0.24)\end{array}$ & $\begin{array}{c}0.000830 \\
(0.24)\end{array}$ & $\begin{array}{c}0.000389 \\
(0.11)\end{array}$ & $\begin{array}{c}-0.000681 \\
(-0.14)\end{array}$ \\
\hline Age 10 Fam. Inc. (upper) / £100/wk. & $\begin{array}{c}0.0109^{* *} \\
(2.73)\end{array}$ & $\begin{array}{c}0.00895^{*} \\
(2.17)\end{array}$ & $\begin{array}{c}0.00861 * \\
(2.07)\end{array}$ & $\begin{array}{c}0.00935^{*} \\
(2.28)\end{array}$ & $\begin{array}{c}0.00887^{*} \\
(2.20)\end{array}$ & $\begin{array}{c}0.0122^{*} \\
(2.40)\end{array}$ \\
\hline Perm. Fam. Inc. (lower) / £100/wk. & $\begin{array}{c}0.0261^{* *} \\
(3.00)\end{array}$ & $\begin{array}{c}0.0283 * * * \\
(3.42)\end{array}$ & $\begin{array}{c}0.0278 * * * \\
\quad(3.48)\end{array}$ & $\begin{array}{c}0.0283 * * * \\
(3.60)\end{array}$ & $\begin{array}{c}0.0287 * * * \\
(3.75)\end{array}$ & $\begin{array}{c}0.0299 * * \\
(3.05)\end{array}$ \\
\hline Perm. Fam. Inc. (upper) / £100/wk. & $\begin{array}{c}0.0369 * * * \\
(4.73)\end{array}$ & $\begin{array}{c}0.0395 * * * \\
(5.13)\end{array}$ & $\begin{array}{c}0.0405^{* * * *} \\
(5.05)\end{array}$ & $\begin{array}{c}0.0375^{* * *} \\
(4.95)\end{array}$ & $\begin{array}{c}0.0388 * * * \\
\quad(5.11)\end{array}$ & $\begin{array}{c}0.0342 * * * \\
\quad(3.44)\end{array}$ \\
\hline Female & $\begin{array}{c}0.00504 \\
(0.97)\end{array}$ & $\begin{array}{c}0.00279 \\
(0.53)\end{array}$ & $\begin{array}{c}0.00246 \\
(0.47)\end{array}$ & $\begin{array}{c}0.00155 \\
(0.29)\end{array}$ & $\begin{array}{c}0.00179 \\
(0.34)\end{array}$ & $\begin{array}{c}-0.00289 \\
(-0.38)\end{array}$ \\
\hline Housing: Own & $\begin{array}{c}0.0191 \\
(1.87)\end{array}$ & $\begin{array}{c}0.0166 \\
(1.68)\end{array}$ & $\begin{array}{c}0.0164 \\
(1.68)\end{array}$ & $\begin{array}{c}0.0138 \\
(1.36)\end{array}$ & $\begin{array}{c}0.0158 \\
(1.57)\end{array}$ & $\begin{array}{c}0.00589 \\
(0.42)\end{array}$ \\
\hline Bracken School Readiness Z-Score & $\begin{array}{c}0.00748 \\
(1.90)\end{array}$ & $\begin{array}{c}0.00763^{*} \\
(1.99)\end{array}$ & $\begin{array}{c}0.00755^{*} \\
(1.99)\end{array}$ & $\begin{array}{c}0.00607 \\
(1.63)\end{array}$ & $\begin{array}{c}0.00690 \\
(1.85)\end{array}$ & $\begin{array}{c}0.0110^{*} \\
(2.20)\end{array}$ \\
\hline Liberal Values Z-Score & & $\begin{array}{c}0.00345 \\
(1.02)\end{array}$ & $\begin{array}{c}0.00352 \\
(1.05)\end{array}$ & $\begin{array}{c}0.00232 \\
(0.69)\end{array}$ & $\begin{array}{c}0.00190 \\
(0.57)\end{array}$ & $\begin{array}{c}0.00717 \\
(1.48)\end{array}$ \\
\hline Trad. Values Z-Score & & $\begin{array}{c}0.0229 * * * \\
(6.44)\end{array}$ & $\begin{array}{c}0.0232^{* * * *} \\
(6.65)\end{array}$ & $\begin{array}{c}0.0222 * * * \\
(6.71)\end{array}$ & $\begin{array}{c}0.0218 * * * \\
(6.72)\end{array}$ & $\begin{array}{c}0.0239 * * * \\
(5.55)\end{array}$ \\
\hline Edu. Values Z-Score & & $\begin{array}{c}0.00618 \\
(1.94)\end{array}$ & $\begin{array}{c}0.00632 \\
(1.97)\end{array}$ & $\begin{array}{c}0.00608 \\
(1.91)\end{array}$ & $\begin{array}{c}0.00614 \\
(1.92)\end{array}$ & $\begin{array}{c}0.00478 \\
(1.08)\end{array}$ \\
\hline Travel Time to Independent school / 10 mins & & & & $\begin{array}{c}-0.0355^{* * *} \\
(-4.51)\end{array}$ & $\begin{array}{c}-0.0305^{* * *} \\
(-4.15)\end{array}$ & $\begin{array}{c}-0.0339 * * \\
(-3.35)\end{array}$ \\
\hline Travel Time to Outstanding School / 10 mins & & & & $\begin{array}{c}0.0221 * * * \\
(3.49)\end{array}$ & & \\
\hline Travel Time to Grammar School / 10 mins & & & & & $\begin{array}{c}0.00869 * * \\
\quad(4.65)\end{array}$ & $\begin{array}{c}{ }^{*} 0.0239 * * * \\
(4.49)\end{array}$ \\
\hline$\underline{\text { Region }}$ & $\sqrt{ }$ & $\sqrt{ }$ & $\sqrt{ }$ & $\sqrt{ }$ & $\sqrt{ }$ & $\sqrt{ }$ \\
\hline$\overline{\mathrm{N}}$ & 5809 & 5809 & 5809 & 5803 & 5803 & 3314 \\
\hline$p$ value of $F$ test of values & . & 0.00 & 0.00 & 0.00 & 0.00 & 0.00 \\
\hline $\mathrm{p}$ value of $\mathrm{F}$ test of trad. values/income interaction & 1 & & 0.31 & 0.33 & 0.32 & 0.26 \\
\hline Residual Degrees of Freedom & 197 & 197 & 197 & 197 & 197 & 174 \\
\hline
\end{tabular}

Notes. Source: University of London. Institute of Education. Centre for Longitudinal Studies (2017b, 2017e, 2017f, 2017c, 2017a, 2018, 2017d). Analysis takes into account survey design and is weighted using MCS-supplied sampling and nonresponse weights. Models Ns are unweighted. Reporting average marginal effects based on underlying probit regression model. School type measurement based on parental reports when cohort member is aged 7, 10 and 14. $t$ statistics in parentheses: * $p<0.05, * * p<0.01, * * * p<0.001$. Omitted categories are as follows: Housing: Rent or Other; Gender: male. 
Table 8: Average marginal effects on probability of attending a private secondary school conditional on having attended a state primary school

\begin{tabular}{|c|c|c|c|c|c|c|}
\hline & $\mathrm{P} 0$ & $\mathrm{P} 1$ & $\mathrm{P} 2$ & P3 & $\mathrm{P} 4$ & P5 \\
\hline Age 10 Fam. Inc. (lower) / £100/wk. & $\begin{array}{c}0.000684 \\
(0.22)\end{array}$ & $\begin{array}{c}0.000961 \\
(0.30)\end{array}$ & $\begin{array}{c}0.000919 \\
(0.29)\end{array}$ & $\begin{array}{c}0.00131 \\
(0.42)\end{array}$ & $\begin{array}{c}0.00114 \\
(0.37)\end{array}$ & $\begin{array}{c}0.00197 \\
(0.47)\end{array}$ \\
\hline Age 10 Fam. Inc. (upper) / £100/wk. & $\begin{array}{c}0.0102 * * * \\
(3.45)\end{array}$ & $\begin{array}{c}0.00907 * * \\
(3.01)\end{array}$ & $\begin{array}{c}0.00929 * * \\
(3.18)\end{array}$ & $\begin{array}{c}0.00952^{* *} \\
(3.20)\end{array}$ & $\begin{array}{c}0.00938^{* *} \\
(3.18)\end{array}$ & $\begin{array}{c}0.0105^{* *} \\
(3.05)\end{array}$ \\
\hline Perm. Fam. Inc. (lower) / £100/wk. & $\begin{array}{c}0.00939 \\
(1.65)\end{array}$ & $\begin{array}{c}0.0110 \\
(1.90)\end{array}$ & $\begin{array}{c}0.0111 \\
(1.92)\end{array}$ & $\begin{array}{l}0.0111 \\
(1.93)\end{array}$ & $\begin{array}{c}0.0111 \\
(1.97)\end{array}$ & $\begin{array}{c}0.00718 \\
(0.96)\end{array}$ \\
\hline Perm. Fam. Inc. (upper) / £100/wk. & $\begin{array}{c}0.00422 \\
(0.59)\end{array}$ & $\begin{array}{c}0.00629 \\
(0.87)\end{array}$ & $\begin{array}{c}0.00552 \\
(0.76)\end{array}$ & $\begin{array}{c}0.00405 \\
(0.56)\end{array}$ & $\begin{array}{c}0.00507 \\
(0.70)\end{array}$ & $\begin{array}{c}0.00935 \\
(1.02)\end{array}$ \\
\hline Female & $\begin{array}{c}0.00484 \\
(1.01)\end{array}$ & $\begin{array}{c}0.00375 \\
(0.78)\end{array}$ & $\begin{array}{c}0.00389 \\
(0.81)\end{array}$ & $\begin{array}{c}0.00365 \\
(0.76)\end{array}$ & $\begin{array}{c}0.00359 \\
(0.75)\end{array}$ & $\begin{array}{c}0.00158 \\
(0.26)\end{array}$ \\
\hline Housing: Own & $\begin{array}{l}0.0107 \\
(1.40)\end{array}$ & $\begin{array}{c}0.00903 \\
(1.21)\end{array}$ & $\begin{array}{c}0.00904 \\
(1.21)\end{array}$ & $\begin{array}{c}0.00835 \\
(1.10)\end{array}$ & $\begin{array}{c}0.00921 \\
(1.23)\end{array}$ & $\begin{array}{c}0.00416 \\
(0.39)\end{array}$ \\
\hline Bracken School Readiness Z-Score & $\begin{array}{c}0.00398 \\
(1.27)\end{array}$ & $\begin{array}{c}0.00433 \\
(1.36)\end{array}$ & $\begin{array}{c}0.00436 \\
(1.37)\end{array}$ & $\begin{array}{c}0.00420 \\
(1.33)\end{array}$ & $\begin{array}{c}0.00430 \\
(1.39)\end{array}$ & $\begin{array}{c}0.00557 \\
(1.53)\end{array}$ \\
\hline Liberal Values Z-Score & & $\begin{array}{c}0.00252 \\
(1.05)\end{array}$ & $\begin{array}{c}0.00252 \\
(1.05)\end{array}$ & $\begin{array}{c}0.00195 \\
(0.79)\end{array}$ & $\begin{array}{c}0.00176 \\
(0.71)\end{array}$ & $\begin{array}{c}0.00332 \\
(0.94)\end{array}$ \\
\hline Trad. Values Z-Score & & $\begin{array}{c}0.0116^{* * * *} \\
(5.50)\end{array}$ & $\begin{array}{c}0.0111^{* * * *} \\
(4.88)\end{array}$ & $\begin{array}{c}0.0107^{* * *} * \\
(4.90)\end{array}$ & $\begin{array}{c}0.0105^{* * * *} \\
(4.85)\end{array}$ & $\begin{array}{c}0.0109 * * * \\
(4.33)\end{array}$ \\
\hline Edu. Values Z-Score & & $\begin{array}{c}0.00352 \\
(1.24)\end{array}$ & $\begin{array}{c}0.00343 \\
(1.21)\end{array}$ & $\begin{array}{c}0.00345 \\
(1.21)\end{array}$ & $\begin{array}{c}0.00350 \\
(1.22)\end{array}$ & $\begin{array}{c}0.00426 \\
(1.11)\end{array}$ \\
\hline Travel Time to Independent school / 10 mins & & & & $\begin{array}{c}-0.00207 * * * \\
(-3.40)\end{array}$ & $\begin{array}{c}*-0.00188^{* *} \\
(-3.25)\end{array}$ & $\begin{array}{c}-0.00173^{*} \\
(-2.44)\end{array}$ \\
\hline Travel Time to Outstanding School / 10 mins & & & & $\begin{array}{c}0.000932 * \\
(2.00)\end{array}$ & & \\
\hline Travel Time to Grammar School / 10 mins & & & & & $\begin{array}{l}0.000344^{* *} \\
\quad(2.73)\end{array}$ & $\begin{array}{c}0.000850 * * \\
(2.79)\end{array}$ \\
\hline Region & $\sqrt{ }$ & $\sqrt{ }$ & $\sqrt{ }$ & $\sqrt{ }$ & $\sqrt{ }$ & $\sqrt{ }$ \\
\hline$\overline{\mathrm{N}}$ & 5536 & 5536 & 5536 & 5531 & 5531 & 3144 \\
\hline$p$ value of $F$ test of values & $\cdot$ & 0.00 & 0.00 & 0.00 & 0.00 & 0.00 \\
\hline $\mathrm{p}$ value of $\mathrm{F}$ test of trad. values/income interaction & & & 0.37 & 0.34 & 0.39 & 0.51 \\
\hline Residual Degrees of Freedom & 197 & 197 & 197 & 197 & 197 & 174 \\
\hline
\end{tabular}

Notes. Source: University of London. Institute of Education. Centre for Longitudinal Studies (2017b, 2017e, 2017f, 2017c, 2017a, 2018, 2017d). Analysis takes into account survey design and is weighted using MCS-supplied sampling and nonresponse weights. Models Ns are unweighted. Reporting average marginal effects based on underlying probit regression model. School type measurement based on parental reports when cohort member is aged 7, 10 and 14. t statistics in parentheses: ${ }^{*} p<0.05, * * p<0.01, * * * p<0.001$. Omitted categories are as follows: Housing: Rent or Other; Gender: male. 
Table 9: Average marginal effects on probability of ever attending a private school among the top $10 \%$ of the income distribution

\begin{tabular}{|c|c|c|c|c|c|}
\hline & $\mathrm{H} 0$ & H1 & $\mathrm{H} 2$ & $\mathrm{H} 3$ & $\mathrm{H} 4$ \\
\hline \multirow[t]{2}{*}{ Perm. Fam. Inc. / £100/wk. } & $0.0465 * * *$ & $0.0503 * * *$ & $0.0518 * * *$ & $0.0501 * * *$ & $0.0546 * * *$ \\
\hline & $(5.93)$ & $(5.84)$ & $(5.62)$ & $(6.24)$ & $(5.00)$ \\
\hline \multirow[t]{2}{*}{ Female } & 0.00514 & -0.00490 & -0.00774 & -0.00975 & -0.0257 \\
\hline & $(0.41)$ & $(-0.40)$ & $(-0.60)$ & $(-0.81)$ & $(-1.77)$ \\
\hline \multirow[t]{2}{*}{ Housing: Own } & -0.0442 & -0.0504 & -0.0678 & -0.0534 & -0.117 \\
\hline & $(-1.16)$ & $(-1.22)$ & $(-1.49)$ & $(-1.31)$ & $(-1.76)$ \\
\hline \multirow[t]{2}{*}{ Bracken School Readiness Z-Score } & 0.0114 & 0.0141 & 0.0101 & 0.0119 & 0.0194 \\
\hline & $(1.18)$ & $(1.34)$ & $(0.98)$ & $(1.15)$ & $(1.25)$ \\
\hline \multirow[t]{2}{*}{ Liberal Values Z-Score } & & -0.00704 & -0.00978 & -0.0112 & -0.00744 \\
\hline & & $(-0.94)$ & $(-1.23)$ & $(-1.43)$ & $(-0.78)$ \\
\hline \multirow[t]{2}{*}{ Trad. Values Z-Score } & & $0.0339 * *$ & $0.0338^{* *}$ & $0.0307 * *$ & $0.0359 * *$ \\
\hline & & (3.04) & $(3.05)$ & $(3.33)$ & $(2.90)$ \\
\hline \multirow[t]{2}{*}{ Edu. Values Z-Score } & & 0.00218 & 0.00249 & 0.00319 & 0.000543 \\
\hline & & $(0.34)$ & $(0.39)$ & $(0.52)$ & $(0.07)$ \\
\hline \multirow[t]{2}{*}{ Travel Time to Independent school / 10 mins } & & & $-0.0374 *$ & $-0.0323 *$ & $-0.0364 *$ \\
\hline & & & $(-2.31)$ & $(-2.47)$ & $(-2.17)$ \\
\hline \multirow[t]{2}{*}{ Travel Time to Outstanding School / 10 mins } & & & 0.0305 & & \\
\hline & & & $(1.92)$ & & \\
\hline Travel Time to Grammar School / 10 mins & & & & $\begin{array}{c}0.0145^{* * * *} \\
(3.41)\end{array}$ & $\begin{array}{c}0.0225^{*} \\
(2.20)\end{array}$ \\
\hline$\underline{\text { Region }}$ & $\sqrt{ }$ & $\sqrt{ }$ & $\sqrt{ }$ & $\sqrt{ }$ & $\sqrt{ }$ \\
\hline$\overline{\mathrm{N}}$ & 597 & 597 & 596 & 596 & 395 \\
\hline$p$ value of $F$ tes & 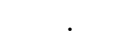 & 0.00 & 0.00 & 0.00 & 0.00 \\
\hline Residual Degrees of Freedom & 197 & 197 & 197 & 197 & 174 \\
\hline
\end{tabular}

Notes. Source: University of London. Institute of Education. Centre for Longitudinal Studies (2017b, 2017e, 2017f, 2017c, 2017a, 2018, 2017d). Analysis takes into account survey design and is weighted using MCS-supplied sampling and nonresponse weights. Sample restricted to top $10 \%$ of permanent equivalsed family income distribution. Models Ns are unweighted. Reporting average marginal effects based on underlying probit regression model. School type measurement based on parental reports when cohort member is aged 7, 10 and 14. $\mathrm{t}$ statistics in parentheses: ${ }^{*} p<0.05,{ }^{* *} p<0.01,{ }^{* * *} p<0.001$. Omitted categories are as follows: Housing: Rent or Other; Gender: male. 
Table 10: Average marginal effects on probability of ever attending a private school exploring informational values of older siblings

\begin{tabular}{|c|c|c|c|}
\hline & 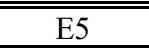 & $\overline{\mathrm{E} 6}$ & $\overline{\text { E7 }}$ \\
\hline Perm. Fam. Inc. (lower) / £100/wk. & $\begin{array}{c}0.0327 * * * \\
(6.33)\end{array}$ & $\begin{array}{c}0.0339 * * * \\
(5.31)\end{array}$ & $\begin{array}{c}0.0237 * * * \\
(5.27)\end{array}$ \\
\hline Perm. Fam. Inc. (upper) / £100/wk. & $\begin{array}{c}0.0577 * * * \\
\quad(9.52)\end{array}$ & $\begin{array}{c}0.0533 * * * \\
(7.89)\end{array}$ & $\begin{array}{c}0.0269^{* * *} \\
(4.01)\end{array}$ \\
\hline Female & $\begin{array}{c}-0.00149 \\
(-0.28)\end{array}$ & $\begin{array}{c}-0.00251 \\
(-0.29)\end{array}$ & $\begin{array}{c}0.00161 \\
(0.23)\end{array}$ \\
\hline Housing: Own & $\begin{array}{c}0.00972 \\
(0.89)\end{array}$ & $\begin{array}{c}0.0148 \\
(0.95)\end{array}$ & $\begin{array}{c}0.00804 \\
(0.69)\end{array}$ \\
\hline Bracken School Readiness Z-Score & $\begin{array}{c}0.00884^{*} \\
(2.19)\end{array}$ & $\begin{array}{c}0.00602 \\
(1.20)\end{array}$ & $\begin{array}{c}0.00397 \\
(0.99)\end{array}$ \\
\hline Liberal Values Z-Score & $\begin{array}{c}0.00201 \\
(0.60)\end{array}$ & $\begin{array}{c}0.00319 \\
(0.75)\end{array}$ & $\begin{array}{c}0.000506 \\
(0.13)\end{array}$ \\
\hline Trad. Values Z-Score & $\begin{array}{c}0.0237 * * * \\
(7.05)\end{array}$ & $\begin{array}{c}0.0241 * * * \\
(5.61)\end{array}$ & $\begin{array}{c}0.00972 * \\
(2.49)\end{array}$ \\
\hline Edu. Values Z-Score & $\begin{array}{c}0.00867^{*} \\
(2.41)\end{array}$ & $\begin{array}{c}0.00729 \\
(1.64)\end{array}$ & $\begin{array}{c}0.00482 \\
(1.26)\end{array}$ \\
\hline Travel Time to Independent school (per 10 mins) & $\begin{array}{c}-0.0398 * * * \\
(-4.79)\end{array}$ & $\begin{array}{c}-0.0301^{* * *} \\
(-3.42)\end{array}$ & $\begin{array}{c}-0.0215^{* *} \\
(-3.32)\end{array}$ \\
\hline Travel Time to Outstanding School (per 10 mins) & $\begin{array}{c}0.0217^{* *} \\
(3.23)\end{array}$ & $\begin{array}{c}0.0270 * * * \\
(3.88)\end{array}$ & $\begin{array}{c}0.0202 * * * \\
(3.65)\end{array}$ \\
\hline Older Sib. at Private School & & & $\begin{array}{c}0.147 * * * \\
(13.56)\end{array}$ \\
\hline Region & $\sqrt{ }$ & $\sqrt{ }$ & $\sqrt{ }$ \\
\hline$\overline{\mathrm{N}}$ & 5803 & 3167 & 3167 \\
\hline valu & 0.00 & 0.00 & 0.05 \\
\hline $\mathrm{F}$ test & 0.04 & 0.24 & 0.87 \\
\hline Residual Degrees of Freedom & 197 & 197 & 197 \\
\hline
\end{tabular}

Notes. Source: University of London. Institute of Education. Centre for Longitudinal Studies (2017b, 2017e, 2017f, 2017c, 2017a, 2018, 2017d). Analysis takes into account survey design and is weighted using MCS-supplied sampling and nonresponse weights. Models Ns are unweighted. Reporting average marginal effects based on underlying probit regression model. School type measurement based on parental reports when cohort member is aged 7, 10 and 14. t statistics in parentheses: $* p<0.05,{ }^{*} p<0.01, * * * p<0.001$. Omitted categories are as follows: Housing: Rent or Other; Gender: male; No older sibling at private school. Models 6 and 7 are restricted to individuals with an older sibling, hence the reduced sample size. 
Figure 1: Predicted probabilities across distribution of parental traditional values at illustrative levels of family income

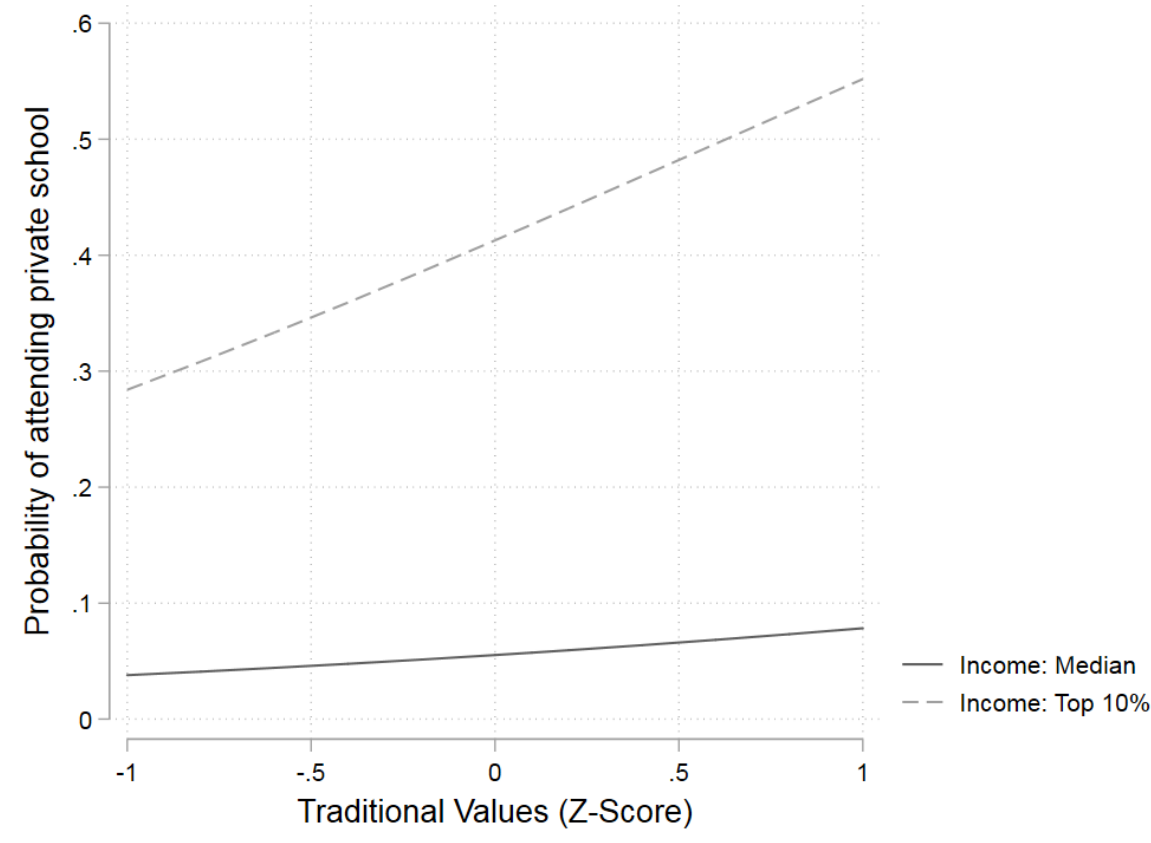

Notes. Predicted probabilities from Model E2 with marginal effects reported in Table 5. All covariates other than family 'permanent' income and traditional values factor are held constant at means. 


\section{Values Measures methodological supplement}

To operationalise parental values, we construct measures based on questions asked to parents when their child is an infant (MCS Wave 1). The questions we use for this are as follows, to which they can respond by saying they strongly agree, agree, neither agree nor disagree, disagree, strongly disagree or can't say:

- Couples who have children should not separate. [NOSEPARATE]

- It is all right for people to have children without being married. [NOTMARRIED]

- A child is likely to suffer if his or her mother works before he/she starts school. [MUMWORKCHILDSUFFER]

- All in all, family life suffers when the woman has a full-time job. [MUMWORKFAMILYSUFFER]

- A single parent can bring up children just as well as a couple can. [SINGLEPARENT]

- Children need their father to be as closely involved in their upbringing as their mother. [FATHERINVOLVED]

- A mother and her family would all be happier if she goes out to work. [MUMWORKHAPPY]

- I would not mind if my child went to a school where half the children were of another race. [INTERRACESCHOOL]

- It is all right for people from different races to get married. [INTERRACEMARRIED]

- I would not mind if a family from another race moved in next door to me. [INTERRACENEIGHBOUR]

- Learning about new things boosts your confidence. [LEARNINGCONF]

- Education helps you to be a better parent. [EDUPARENT]

- Learning to use a computer is more trouble than it's worth [LEARNINGCOMP]

We begin by conducting an exploratory factor analysis (using the method of principal factors) on a correlation matrix of the thirteen values measures, taking into account the MCS-supplied non-response weights. A scree plot (Figure S1) suggests that most variance is extracted parsimoniously using three latent factors. We then use an orthogonal varimax rotation in order to produce uncorrelated factors, given that all three are used in our regression modelling.

Given the ordinal (rather than continuous) nature of the individual measures, we use a polychoric correlation matrix as the basis of the exploratory factor analysis to derive continuous measures of latent values (Kolenikov and Angeles, 2009). We also repeated the analysis without applying nonresponse weights, using a Pearson's covariance matrix, and a combination of both of these. The resulting factor measures are all extremely highly correlated $(r>=0.95)$ suggesting neither of these methodological changes makes much difference to the construction of the factor scores.

These three factors load strongly onto the following measurement variables, respectively (none of the three extracted latent factors loads strongly onto MUMWORKHAPPY):

1. NOTMARRIED, INTERRACESCHOOL, INTERRACENEIGHBOUR, INTERRACEMARRIED and LEARNINGCONF;

2. MUMWORKCHILDSUFFER, MUMWORKFAMILYSUFFER, NOTMARRIED, NOSEPARATE;

3. NOTMARRIED, FATHERINVOLVED, SINGLEPARENT, NOSEPARATE, LEARNINGCONF, LEARNINGCOMP, EDUPARENT 
Figure S1: Scree plot from polychoric exploratory factor analysis of parental values variables

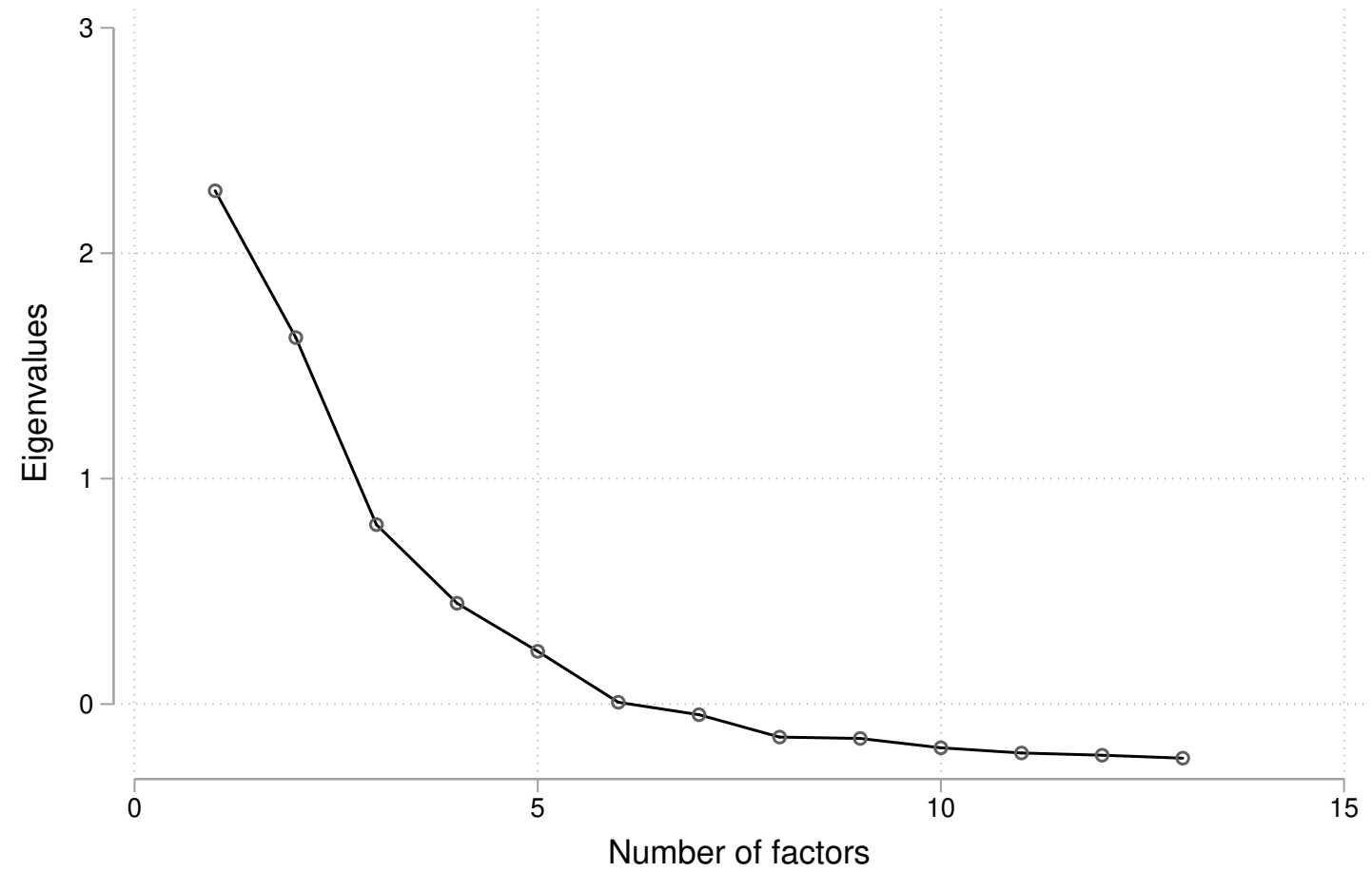

Notes. Source: UCL Institute of Education Centre for Longitudinal Studies (2017). Millennium Cohort Study: First Survey, 2001-2003. [data collection]. 12th Edition, [original data producer(s)]. UK Data Service. SN: 4683, http://doi.org/10.5255/UKDA-SN-4683-4.

To simplify the interpretation of these factors, while maintaining the broad structure implied by this exploratory factor analysis, we conduct confirmatory factor analysis of a simplified version of the above structure:

1. Liberal Values factor: INTERRACESCHOOL, INTERRACENEIGHBOUR, INTERRACEMARRIED

2. Traditional Values factor: MUMWORKCHILDSUFFER, MUMWORKFAMILYSUFFER, NOTMARRIED, NOSEPARATE;

3. Education Values factor: LEARNINGCONF, LEARNINGCOMP, EDUPARENT.

In our measurement model, the three factors are allowed to correlate with one another, which improves the model fit, although the resulting correlations are not particularly strong. There is essentially no correlation between our Traditional and Education values measures $(r=0.06)$, there is a negative correlation between our Traditional and Liberal values measures $(r=-0.36)$, and there is a positive correlation between our Liberal and Education values measures $(r=0.47)$. This intuitively fits with the constructs we are trying to measure.

We test this proposed factor structure using Generalised Structural Equation Modelling (SEM) accounting for the ordinal nature of the response variables using an ordered logistic link function and the MCS-provided non-response weights. This is carried out using MPlus 6.12. We also repeated the analysis without applying the non-response weights and using (non-Generalised) Structural Equation Modelling i.e. ignoring the ordinal nature of the measurement variables, again with and without application of non-response weights. The resulting factor measures are all extremely highly correlated $(r \geq 0.98)$ suggesting these methodological changes makes little difference to the substantive findings. As such, given software restrictions on the computer system on which our main analysis is conducted, we ultimately use the non-Generalised SEM results in our modelling. 
Goodness of fit measures from this model are as follows: Root mean squared error of approximation = 0.127 ; Comparative fit index $=0.794$; Tucker-Lewis index $=0.710$. While these fall short of most rules of thumb for good fit (Hu and Bentler, 1999), we judge them to be adequate for our purposes. We take this view particularly as exploration of modification indices suggests that changes that improve the fit are constraints that we have deliberately chosen to impose. For example, the fit could be improved by allowing multiple factors to predict a number of the measurement items.

We extract predictions of the latent factors from the GSEM model and normalise these to have mean zero and unit standard deviation. These means are reported for each level of the measurement variables in Table S1.

Table S1: Mean latent values factors by levels of measurement variables

\begin{tabular}{|c|c|c|c|}
\hline Variable & Liberal Values & Traditional Values & Education Values \\
\hline \multicolumn{4}{|c|}{ MUMWORKCHILDSUFFER } \\
\hline Strongly disagree & 0.27 & -1.38 & 0.24 \\
\hline Disagree & 0.03 & -0.63 & -0.10 \\
\hline Neither agree nor disagree & -0.03 & 0.07 & -0.08 \\
\hline Agree & -0.11 & 0.95 & 0.02 \\
\hline Strongly agree & -0.08 & 1.69 & 0.45 \\
\hline \multicolumn{4}{|l|}{ MUMWORKFAMILYSUFFER } \\
\hline Strongly disagree & 0.42 & -1.59 & 0.19 \\
\hline Disagree & 0.10 & -0.80 & -0.13 \\
\hline Neither agree nor disagree & -0.04 & -0.02 & -0.13 \\
\hline Agree & -0.12 & 0.70 & 0.08 \\
\hline Strongly agree & -0.10 & 1.56 & 0.45 \\
\hline \multicolumn{4}{|l|}{ MUMWORKHAPPY } \\
\hline Strongly agree & 0.17 & 0.05 & 0.57 \\
\hline Agree & 0.04 & -0.14 & 0.15 \\
\hline Neither agree nor disagree & 0.04 & -0.20 & -0.04 \\
\hline Disagree & -0.13 & 0.30 & -0.05 \\
\hline Strongly disagree & 0.08 & 0.81 & 0.30 \\
\hline \multicolumn{4}{|l|}{ NOTMARRIED } \\
\hline Strongly agree & 0.50 & -0.48 & 0.22 \\
\hline Agree & -0.13 & -0.11 & -0.17 \\
\hline Neither agree nor disagree & -0.36 & 0.33 & -0.03 \\
\hline Disagree & -0.26 & 0.88 & 0.03 \\
\hline Strongly disagree & -0.08 & 1.42 & 0.36 \\
\hline \multicolumn{4}{|l|}{ FATHERINVOLVED } \\
\hline Strongly disagree & 0.07 & -0.61 & -0.27 \\
\hline Disagree & -0.28 & -0.31 & -0.55 \\
\hline Neither agree nor disagree & -0.10 & -0.25 & -0.39 \\
\hline Agree & -0.17 & -0.02 & -0.21 \\
\hline Strongly agree & 0.19 & 0.11 & 0.30 \\
\hline \multicolumn{4}{|l|}{ SINGLEPARENT } \\
\hline Strongly agree & 0.39 & -0.31 & 0.05 \\
\hline Agree & -0.06 & -0.16 & -0.14 \\
\hline Neither agree nor disagree & -0.11 & 0.09 & -0.01 \\
\hline Disagree & -0.14 & 0.38 & 0.19 \\
\hline Strongly disagree & -0.27 & 1.13 & 0.35 \\
\hline \multicolumn{4}{|l|}{ INTERRACESCHOOL } \\
\hline Strongly disagree & -1.52 & 0.33 & 0.03 \\
\hline Disagree & -1.14 & 0.22 & -0.09 \\
\hline
\end{tabular}

Continued on next page... 


\begin{tabular}{|c|c|c|c|}
\hline Variable & Liberal Values & Traditional Values & Education Values \\
\hline Neither agree nor disagree & -0.65 & 0.03 & -0.28 \\
\hline Agree & 0.04 & -0.03 & -0.14 \\
\hline Strongly agree & 0.98 & -0.08 & 0.44 \\
\hline \multicolumn{4}{|l|}{ INTERRACENEIGHBOUR } \\
\hline Strongly disagree & -2.79 & 0.30 & -0.11 \\
\hline Disagree & -2.19 & 0.24 & -0.36 \\
\hline Neither agree nor disagree & -1.22 & 0.20 & -0.36 \\
\hline Agree & -0.12 & 0.03 & -0.17 \\
\hline Strongly agree & 1.10 & -0.18 & 0.47 \\
\hline \multicolumn{4}{|l|}{ INTERRACEMARRIED } \\
\hline Strongly disagree & -1.01 & 0.79 & -0.23 \\
\hline Disagree & -1.04 & 0.78 & -0.19 \\
\hline Neither agree nor disagree & -0.87 & 0.26 & -0.31 \\
\hline Agree & -0.18 & 0.01 & -0.18 \\
\hline Strongly agree & 0.83 & -0.24 & 0.44 \\
\hline \multicolumn{4}{|l|}{ NOSEPARATE } \\
\hline Strongly disagree & 0.30 & -0.93 & -0.09 \\
\hline Disagree & 0.12 & -0.44 & -0.09 \\
\hline Neither agree nor disagree & -0.08 & -0.01 & -0.04 \\
\hline Agree & -0.13 & 0.52 & 0.01 \\
\hline Strongly agree & 0.02 & 1.19 & 0.53 \\
\hline \multicolumn{4}{|l|}{ LEARNINGCONF } \\
\hline Strongly disagree & -0.46 & -0.90 & -4.10 \\
\hline Disagree & -0.41 & -0.22 & -2.85 \\
\hline Neither agree nor disagree & -0.37 & -0.05 & -1.74 \\
\hline Agree & -0.12 & -0.01 & -0.40 \\
\hline Strongly agree & 0.28 & 0.04 & 1.07 \\
\hline \multicolumn{4}{|l|}{ LEARNINGCOMP } \\
\hline Strongly agree & 0.29 & 0.19 & -0.53 \\
\hline Agree & -0.16 & 0.25 & -0.69 \\
\hline Neither agree nor disagree & -0.20 & 0.24 & -0.51 \\
\hline Disagree & -0.09 & -0.00 & -0.11 \\
\hline Strongly disagree & 0.24 & -0.18 & 0.58 \\
\hline \multicolumn{4}{|l|}{ EDUPARENT } \\
\hline Strongly disagree & 0.17 & -0.44 & -0.93 \\
\hline Disagree & -0.05 & -0.30 & -0.81 \\
\hline Neither agree nor disagree & -0.08 & -0.09 & -0.38 \\
\hline Agree & -0.08 & 0.06 & 0.05 \\
\hline Strongly agree & 0.26 & 0.25 & 1.04 \\
\hline Sample Mean & 0.00 & 0.00 & 0.00 \\
\hline
\end{tabular}

Notes. Source: UCL Institute of Education Centre for Longitudinal Studies (2017). Millennium Cohort Study: First Survey, 2001-2003. [data collection]. 12th Edition, [original data producer(s)]. UK Data Service. SN: 4683, http://doi.org/10.5255/UKDASN-4683-4. Analysis accounts for MCS survey design and MCS-supplied sampling and non-response weights. 